Año L. urtea

$126-2018$

Uztaila-abendua Julio-diciembre

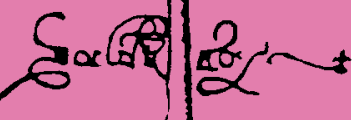

(t)

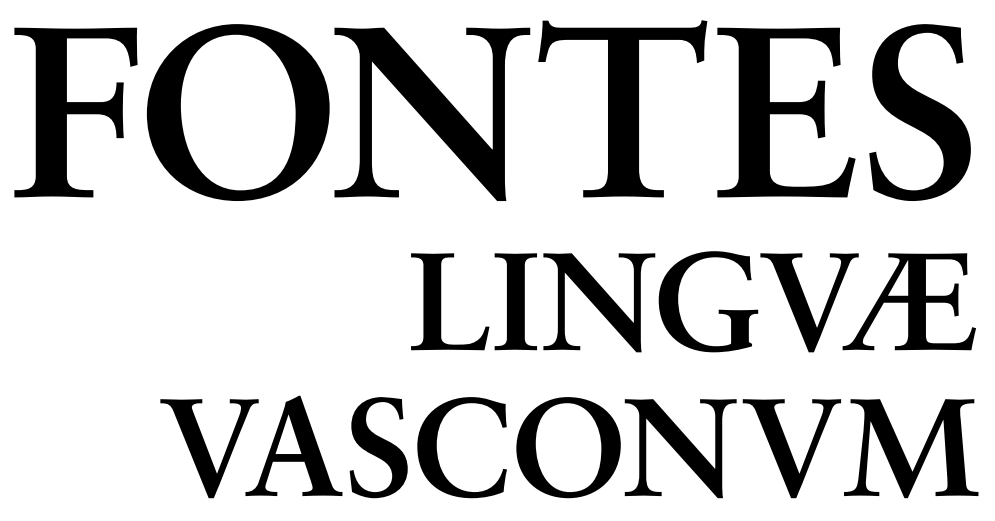

STVDIA ET DOCVMENTA

SEPARATA

\title{
A tale of two reciprocal anaphors in Basque: preliminaries
}

Xabier Artiagoitia

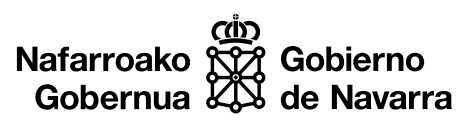

- 00 


\section{A tale of two reciprocal anaphors in Basque: preliminaries}

Euskarazko anafora elkarkari biren kontakizuna: hastapenak

Historia de dos anáforas recíprocas vascas: preliminares

Xabier ARTIAgOITIA

UPV/EHU

xabier.artiagoitia@ehu.eus

This article is dedicated to Jon Ortiz de Urbina; I just hope it gets close to the high standards to which he has accustomed us over the years. I am grateful to M. Huarte for her help with the manuscript and to two anonymous reviewers for their generous comments; remaining errors are only mine.

Submission: 16/03/2018. Provisional acceptance: 06/06/2018. Final acceptance: 16/07/2018. 


\begin{abstract}
This article provides a typological perspective of Basque reciprocal expressions and reviews previous accounts of the difference between the Basque reciprocal anaphors elkar and bata bestea 'each other, one another'. Moreover, it presents abundant data drawn from the Basque literary tradition to show that Rebuschi's $(1988,1989)$ first account is in fact correct and that the predictions made by his later (1993) account regarding the distribution of bata bestea are not fulfilled. The overview of the usage patterns for bata bestea throughout the Basque literary tradition also confirms a high degree of homogeneity across dialects and periods. The article closes introducing further syntactic and interpretive differences between the two reciprocal anaphors, which should set the basis for a future account.
\end{abstract}

Keywords: reciprocals; binding; syntax; Basque texts.

\title{
LABURPENA
}

Artikuluak, euskal egitura elkarkarien azterketa tipologikoa egin ondoren, elkar eta bata bestea izenordain elkarkariez aurretik emandako azterbideak berrikusten ditu. Euskal testuetatik ateratako adibide ugariren bidez artikuluak frogatzen du Rebuschiren hasierako azterbidea zuzena dela eta haren bigarren azterbideak (Rebuschi 1993) bata bestea elkarkariarentzat egiten dituen predikzioak ez direla euskal testuetan betetzen. Euskal testuetako testigantzak arakatzeak erakusten du, halaber, bata bestea-ren erabileran ez dagoela ezberdintasun mamizkorik euskalki eta aroetan barrena. Artikuluak amaieran elkar eta bata bestea elkarkariez lehenago deskribatu gabeko alde sintaktiko eta interpretatibo gehiagoren berri ematen du, etorkizunean azterbide oso bat garatzen laguntzeko asmoz.

Gako hitzak: elkarkariak; uztardura; sintaxia; euskal testuak.

\section{RESUMEN}

Tras realizar un acercamiento tipológico a las construcciones recíprocas del euskera, el artículo revisa los análisis anteriores de las diferencias entre las anáforas recíprocas elkar y bata bestea 'uno otro'. Se presentan abundantes datos de la tradición literaria vasca que demuestran que la propuesta inicial de Rebuschi sobre la distribución de bata bestea es correcta, y que las predicciones realizadas por su ulterior análisis no son adecuadas. La revisión de los patrones y variaciones de uso de dicha anáfora revela, además, un alto grado de homogeneidad en lo referente a los dialectos, así como en lo tocante a la historia de la lengua. El artículo finaliza presentando nuevas diferencias entre las dos anáforas, las cuales deberían servir como base para un estudio posterior más pormenorizado.

Palabras clave: anáfora recíproca; ligamiento; sintaxis; textos vascos. 
1. INTRODUCTION. 2. BASICS ABOUT BASQUE RECIPROCALS. 3. BASQUE RECIPROCALS From a typological perspective. 4. Previous treatments of bata bestea. 4.1. Grammarians other than Rebuschi. 4.2. Rebuschi's account of the distinction between elkar and bata bestea. 5. REBUSCHI'S DILEMMA'S RESOLUTION: BATA BESTEA IN THE BASQUE LITERARY TRADITION. 5.1. The anaphor bata bestea: when and how it is found. 5.2. When an ergative subject binds the anaphor: distribution of batak bestea vs bata bestea. 5.3. On Rebuschi's (1993) unfulfilled predictions. 6. NOTES FOR FURTHER STUDY. 6.1. Subject reciprocal anaphors? 6.2. Singular and plural antecedents. 6.3. Symmetric and alignment predicates. 6.4. Group reading. 7. CONCLUSIONS. 8. REFERENCES.

\section{INTRODUCTION ${ }^{1}$}

This article is very modest in scope: after reviewing the linguistic literature on both reciprocal Basque anaphors elkar and bata bestea, it presents abundant evidence to show that the characterization of bata bestea depicted in Rebuschi $(1988,1989)$ is correct and defies the predictions made by his later account (Rebuschi, 1993). The evidence is drawn from literary texts of all periods and constitutes by itself an interesting body of data, due to the apparent variation across periods and dialects in the forms of the bipartite anaphor bata bestea. The variation is apparent because, as suggested in Urrutia, Goitia and Artiagoitia (2013), there is in fact more unity and uniformity in the use of bata bestea than a superficial look might make one suspect. The confirmation that the difference between bata bestea and elkar reduces to the fact that the latter needs to be bound in the smallest domain available whereas the former only needs to be bound by the first c-commanding subject, far from being a

1. I use the following abbreviations throughout the article: $\mathrm{ABS}=$ absolutive, $\mathrm{ACC}=$ accusative, $\mathrm{ART}=$ article, AUX $=$ auxiliary, COMP $=$ complementizer, $\mathrm{DAT}=$ dative, $\mathrm{DGV}=$ Diccionario General Vasco $=$ Mitxelena $\&$ Sarasola 1987-2011, DP = determiner phrase, EGLA = Euskaltzaindia 1993, ERG = ergative, GEN = genitive, HEE $=$ Hualde, Elordieta \& Elordieta 1994, INST $=$ instrumental, LIT = literally, LOC = locative, NBD = Narrow Binding Domain, NOM $=$ nominative, $\mathrm{PART}=$ partitive determiner, $\mathrm{PST}=$ past tense, $\mathrm{POST}=$ postposision, $\mathrm{PL}$ $=$ plural, $\mathrm{PRES}=$ present tense, $\mathrm{RECP}=$ reciprocal, $\mathrm{REF}=$ reflexive, $\mathrm{SB}=$ standard $\mathrm{Basque}, \mathrm{SG}=$ singular, $\mathrm{WBD}=$ Wide Binding Domain. The Basque examples are glossed following the Leipzig glossing rules; where rendered irrelevant for the point under discussion, morpheme-by-morpheme glosses have been simplified or omitted. As usual, old examples are cited with modern orthography and stating the page number of the first edition; examples from the Bible follow the usual citation format. 
result in itself, simply poses the question of why these differences should arise in the first place.

In a minimalist context, where binding theory as such is no longer taken as a separate module of grammar but hopefully reducible to other more basic operations such as movement (cfr. Hornstein, 2001), or Agree ( $c f r$. Reuland, 2011; Picallo, 2015), the remarks I make here can only be taken as preliminary and should simply help lay the basis for a future account.

The article is structured as follows: section 2 presents a simple description of the different ways Basque has to express reciprocal constructions; section 3 focuses on the typological characterization of the main two reciprocal anaphors, viz. bata bestea and elkar; section 4 reviews the previous treatments of bata bestea in the literature with special attention to Rebuschi's work; section 5 provides the body of data to confirm Rebuschi's original treatment of bata bestea (as opposed to his last treatment in Rebuschi, 1993) and shows, on broader terms, how the use and shape of the anaphor has evolved in the Basque language. Section 6 , in turn, makes a few comments on the syntactic and semantic characterization of bata bestea; section 7 summarizes the conclusions of the article. In the remainder of the article I assume Zuazo's (2014) division of Basque present-day dialects into Western (W), Central (C), Navarrese, Navarro-Labourdin (NL) and Souletin (S); however, as it is well-known, this state of affairs may not reflect the situation in previous stages of the language, where Labourdin and Low Navarrese were considered separate dialects; therefore, for the $19^{\text {th }}$ century and previous written texts, I thus use the term Navarro-Labourdin implying 'Low Navarrese and/or Labourdin' dialects.

\section{BASICS ABOUT BASQUE RECIPROCALS}

The definition of reciprocity is beyond the scope of this article, but let us assume, for the sake of simplicity, the intuitive idea that reciprocal constructions are those which are conventional or typical for the expression of mutual situations such that «with two or more participants $(\mathrm{A}, \mathrm{B}, \ldots)$ in which for at least two of the participants $\mathrm{A}$ and $\mathrm{B}$, the relation between $A$ and $B$ is the same as the relation between $B$ and $A »$ (Haspelmath, 2007, p. 2088). Once we clarify this, and putting aside the different kinds of reciprocity or the type of inherently reciprocal/symmetrical predicates, it can safely be said that Basque has three typical reciprocal constructions: the two realized with the reciprocal anaphors elkar and bata bestea respectively, and the detransitivization strategy found with some verbs. I start with the latter.

Reciprocal constructions via detransitivization consist of treating a bivalent verb as monovalent, in pretty much the same strategy used for reflexivization (Ortiz de Urbina, 1989, p. 188ff):

(l) a. Jone-k eta Miren-ek Ane ezagutzen dute Jone-ERG and Miren-ERG Ane know AUX

'Jone and Miren know Ane' 


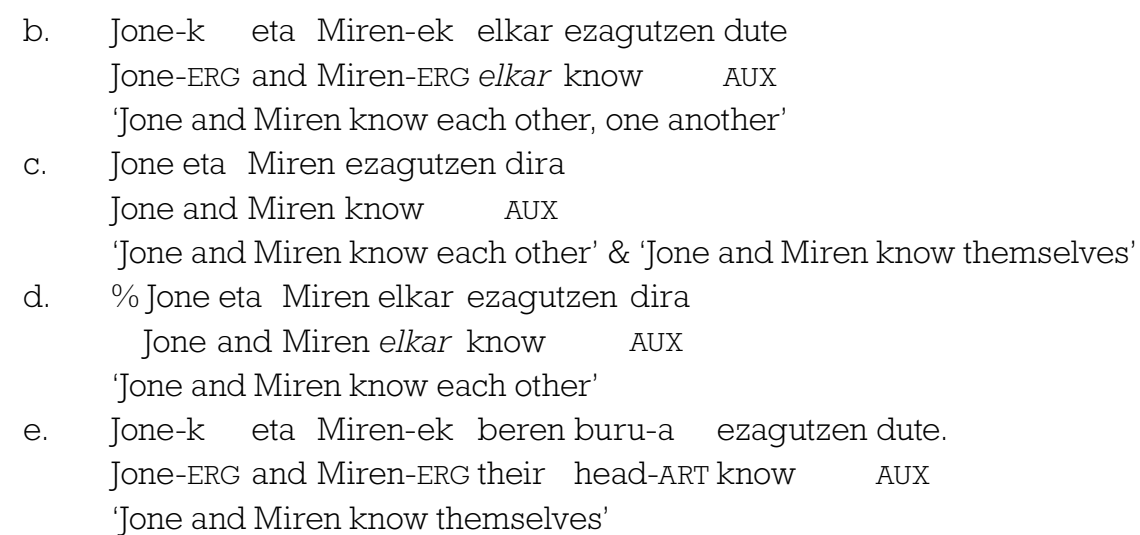

A verb like ezagutu 'know' usually takes an ergative experiencer argument and an absolutive argument together with the transitive auxiliary "edun 'have'; the absolutive argument can be the pronominal anaphor elkar (cfr. 1b); the detransitivazion strategy removes one argument, and the verb simply gets one (conjoined or plural) DP marked absolutive and the intransitive auxiliary izan 'be'. This is exactly the same strategy used for reflexivization; hence, (1c) -due to its plural subject- is in fact ambiguous between a reciprocal and a reflexive reading, equivalent to (1e) with the reflexive anaphor beren burua 'themselves' (literally 'their head') as the absolutive object. For some speakers, there exists also the possibility of combining the detransitivization strategy with the presence of the reciprocal anaphor elkar (cfr. 1d).

This detransitivization process is generally mentioned in Basque grammars; see in particular Euskaltzaindia $(1985$, p. 111; 1987, p. 55; 1993, p. 213), Ortiz de Urbina (1989), Etxepare (2003, p. 381ff), Artiagoitia (2003, p. 617), De Rijk (2008, p. 281). However, Etxepare (2003) is, to my mind, the only author who tries to pinpoint the limits of the strategy. The mixed strategy $(=1 \mathrm{~d})$ is expressly mentioned in the Basque General Dictionary and in Hualde, Elordieta and Elordieta (1994, p. 196).

With respect to elkar and bata bestea, both are taken to be reciprocal pronouns or, in the case of the second, expressions. Elkar, the etymology of which is generally taken to be "hark har 'that.ERG that' after Mitxelena (1977, p. 69), who credits Uhlenbeck (1928, p. 168) for the proposal, is a simple underived word synchronically and does not have any number morphology yet it usually takes a plural antecedent; it can be case marked with absolutive, dative, genitive or appear as a complement to any adposition. Crucially, it cannot be case-marked ergative, which is generally taken as indication that it cannot be in subject position ( $c f r$. Salaburu, 1986a, p. 363, 370):

(2) a. Jone-k eta Miren-ek elkarr-i esku-a eman diote Jone-ERG and Miren-ERG elkar-DAT hand-ART give AUX

'Jone and Miren shook hands with each other'

b. Jone eta Miren elkarr-en etsai bihurtu dira Jone and Miren elkar-GEN enemy become AUX 'Jone and Miren became each other's enemy' 
c. Jone eta Miren elkarr-ekin haserretu eta elkarr-ez gaizki esaka hasi dira Jone and Miren elkar-with get angry and elkar-INST badly saying start AUX 'Jone and Mary got angry at each other and started talking badly about one another'

d. *Elkarr-ek Jon eta Miren maite ditu elkar-ERG Jon and Miren love AUX

'*Each other love Jon and Miren' (Salaburu, 1986a, p. 363) ${ }^{2}$

The reciprocal expression bata bestea has received much less attention in the Basque tradition, as we will see in section 4 ; it is a two-member anaphor consisting of the numeral bat 'one', generally followed by the article, and the word for 'other', either beste (Western, Central and Souletin Basque, some varieties of Navarro-Labourdin) or bertze (Navarrese, varieties of Navarro-Labourdin and some writers of Souletin) followed by the article. For convenience, I cite the anaphor under the name bata bestea. The numeral part shows two kinds of variation: one has to do with whether the article is used or not, but most Basque writers have used the variant with article; the second kind of variation has to do with whether the numeral bears ergative case or not when the antecedent is a subject bearing ergative case; again most writers use the variant showing ergative case. I summarize the four options here:

(3) Jone-k eta Miren-ek bat-a-k beste-a ezagutzen dute.
Jone-ERG and Miren-ERG one-ART-ERG other-ART know AUX
b. Jone-k eta Miren-ek bat-ek beste-a ezagutzen dute.
Jone-ERG and Miren-ERG one-ERG other-ART know AUX
(less common than a)
Jone-k eta Miren-ek bat-a beste-a ezagutzen dute. (less than a)
Jone-ERG and Miren-ERG one-ART other-ART know AuX
Jone-k eta Miren-ek bat beste-a ezagutzen dute. (far less than b)
Jone-ERG and Miren-ERG one other-ART know AUX
'Jone and Miren know one another'

Just like with elkar, bata bestea may bear any case marking on the second member of the anaphor but hardly any example is generally found in the literary tradition with ergative case, $i$. e. with bata bestea in the subject position of a transitive clause (cfr. Urrutia, Goitia \& Artiagoitia, 2013); however, Hualde, Elordieta and Elordieta (1994, p. 177) provide an example with ergative case on bestea for Lekeitio Basque $(=4 \mathrm{~d})$ :

2 There is, however, an isolated, well-known, example by Hiriart-Urruty: Ohoinak eta bertze gaizki-egileak behar baititugu elgarrek elgarren lurretarik urrundu 'Because we ought to move away ourselves thieves and other wrong-doers from each other's lands' (J. Hiriart-Urruty, Zezenak Errepublikan, 87, 1972 [1897]). 
(4) a. Jone-k eta Miren-ek bat-a-k beste-a-ri esku-a eman diote. Jone-ERG and Miren-ERG one-ART-ERG other-ART-DAT hand-ART give AUX 'Jone and Miren shook hands with each other'

b. Jone eta Miren bat-a beste-a-ren etsai bihurtu dira Jone and Miren one-ART other-ART- GEN enemy become AUX 'Jone and Miren became each other's enemy'

c. Jone eta Miren bat-a beste-a-rekin haserretu eta bat-a beste-a-z Jone and Miren one-ART other-ART-with get angry and one-ART other-ART-INST hasi dira gaizki esaka start AUX badly saying 'Jone and Mary got angry at each other and started talking badly about one another'

d. ês-takiže bat-a-bestí-a-k ser égingo dabe-n NEG-know one-ART-Other-ART-ERG what do AUX-COMP 'They do not know what each other will do'

In Lekeitio Basque, the anaphor bata bestea has become a grammaticalized invariant anaphor and, hence, the first member of the anaphor never gets ergative case.

Leaving the discussion of further differences between elkar and bata bestea for subsequent sections, one offhand and obvious difference between elkar and bata bestea is the morphosyntactic composition of both: elkar is a simple word and as such it may take place in compounds and derived words like the following:

(5) a. derived words: elkargo 'association', elkartasun 'solidarity', elkartu 'get together, unite'

b. Compound words: elkarbizitza 'cohabitation, living together' (< elkar + bizitza 'life, living'), elkarrizketa 'conversation' (< elkar + hizketa 'conversation'), elkarlan 'teamwork, collaboration' (< elkar + lan 'work')

Ocassionally, elkar is used to translate the Romance prefix inter- in newly coined compounds like elkarrekintza 'interaction', attested in Euskaltzaindia (2016), or elkarmendekotasun 'interdependence' (Sarasola, 2008-2018). In most cases, elkar does not give rise to verbal compounds but Sarasola's (2008-2018) dictionary lists a half dozen of them: elkarbanatu 'divide', elkargurutzatu 'cross each other', elkarjosi 'sew together', elkarlotu 'tie together', elkarreragin 'affect each other', elkartrukatu 'interchange'. All of this evidence suggests that elkar is both a head and a phrase:

$$
\left[[\text { elkar }]_{\mathrm{D}}\right]_{\mathrm{DP}}
$$

Bata bestea, on the other hand, is composed by what appears to be a sequence of two noun phrases or, rather, two DPs: [Q-D] + [beste-D]. Depending on whether or not the first member of the anaphor appears with the article, the first phrase would appear to be a single QP. Thus, we may think of the following syntactic representation: 
(7)

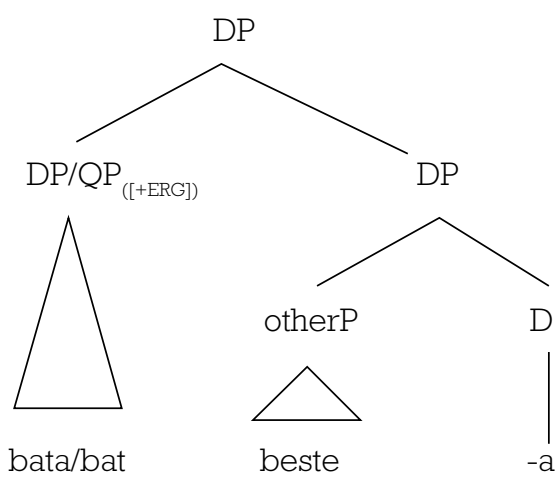

I leave the status of beste open; although generally regarded as a pronoun or a determiner, it is also a sort of quantifier in comparative structures: nabi duzun beste diru 'as much money as you want'. In any case, bata bestea is totally excluded from derivation and compounds:

(8) *bata-bestea-tasun, *bata-bestea-tu
b. *bata-bestea-lan

This squares well with the idea that a bipartite (and juxtaposed) noun phrase will not be available to further morphological operations.

Having outlined the very basics of Basque reciprocals ${ }^{3}$ let us take a look at them from a typological perspective.

\section{BASQUE RECIPROCALS FROM A TYPOLOGICAL PERSPECTIVE}

In this section, I go over Köning and Kokutani's (2006) and Evans's (2008) typological classification of reciprocal expressions and, additionally, I briefly review the work of two generative syntacticians on reciprocals, Everaert (2000, 2005, 2008) and Siloni (2012).

König and Kokutani (2006) develop a preliminary typology of reciprocal constructions based on Faltz's (1985) typology of reflexives. They draw a distinction between verbal strategies on the one hand and nominal strategies on the other. Verbal strategies are further subdivided into synthetic and compound strategies:

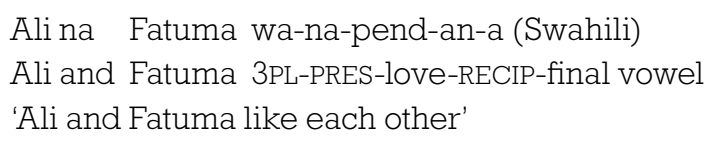

3 See also HEE (1994, p. 178) and Artiagoitia (2003, p. 618), who mention the combination of the quantifier bakoitza 'each' and beste + noun. 
(10)

\author{
Tamen da-lai-da-qù (Mandarin) \\ 3PL beat-come-beat-go \\ 'They beat each other' \\ (König and Kokutani, 2006, p. 276)
}

Nominal strategies are also subdivided into pronominal and quantificational:

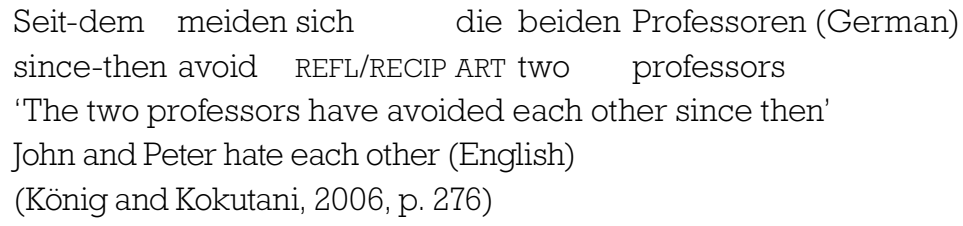

The authors make it clear that languages often use more than one strategy: for example, Romance languages and German combine both nominal strategies (pronominal and quantificational), Japanese has both a compound verbal strategy and a quantificational one. Although they mention that there are languages where reflexive structures are similar to reciprocal structures (e. g. German sich and Romance se/si and the like, analyzed as pronominal strategies), no room is left for detranstivization processes of the Basque type in section 2.

König and Kokutani (2006, p. 278) mention Basque elkar as a verbal marker that gives rise to a compound kind of verbal reciprocal. The example provided suggests something else, though:

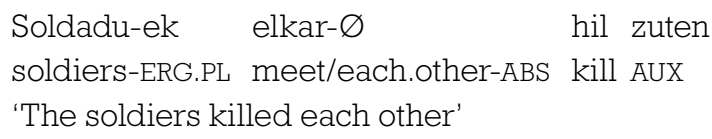

That is to say, the authors claim that elkar may come from the verb elkartu 'meet, come together', in which case elkar hil would be some kind of compound verb (just like we see elkar in words like elkarrizketa or elkartasun); note, however, that they still render elkar as NP marked absolutive $e^{4}$ Even if we accepted that elkar may give rise to compound verbs, it is by all means clear that elkar is a DP subject to topicalization (14a) or focalization (14b); it can be case-marked with dative or can be a complement to other postpositions (14c):

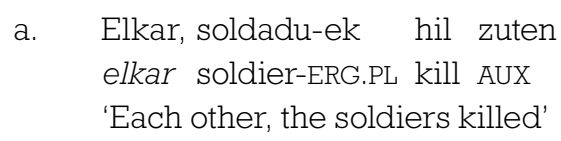

4 They acknowledge in a footnote that it is not all that clear whether the marker derives from the verb or the other way around. Nonetheless, they stick to their position that examples like (13) are of the compoud type. 
b. ELKAR hil zuten soldaduek

'It's each other that the soldiers killed'

c. Elkarr-i esku-a eman diote, elkarr-ekin afaldu dute elkar-DAT hand-ART give AUX elkar-with dine AUX

'They shook hands with each other, they had dinner together'

Thus, if anything, elkar would be an example of a pronominal strategy in König and Kokutani's (2006) typology of reciprocal expressions. Bata bestea would side with the quantificational strategy.

In the refined typology of reciprocal constructions developed by Evans (2008), the author makes a difference between single clause strategies and those based on multiple clauses; regarding the first group, he even makes a distinction between NP-marking or argument-marking strategies, verb-marking strategies, conjunct strategies, and adverbial or modifier strategies. Here is an example of each:

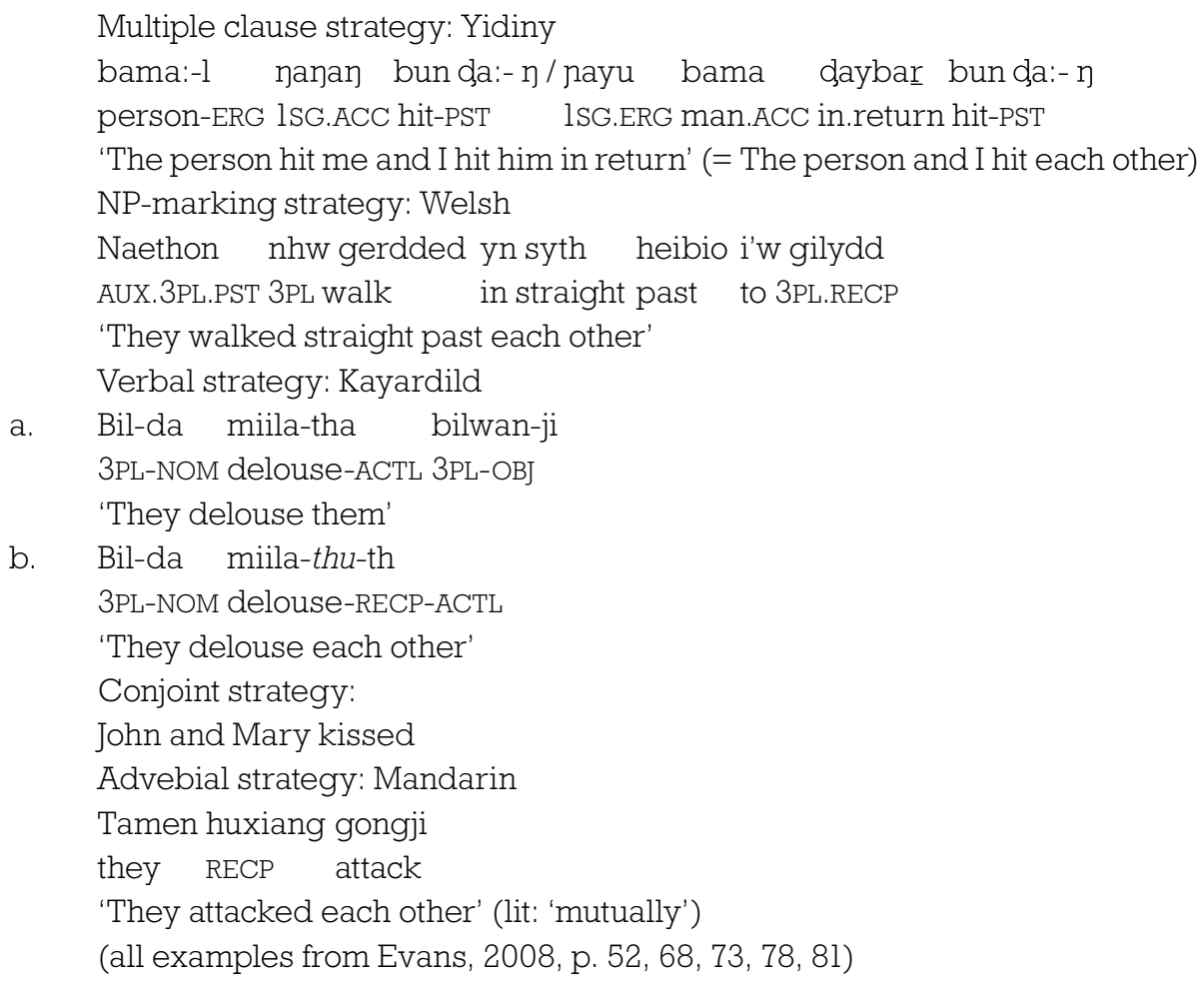

The NP-marking strategy is further subdivided into the type of marking that is available crosslinguistically; Evans (2008) mentions bipartite quantifiers or NPs, reciprocal nominals, reciprocal pronouns (both free or bound), reciprocal marking on a single NP, or reciprocal marking on two NPs. Interestingly, Evans (2008, p. 54) mentions elkar as a good example of a reciprocal nominal displaying «noun-like morphology and trigger[ing] third person singular agreement on the verb, but which do not mark the reciprocal nominal for possession» (unlike in Welsh, for example). His main source 
is Saltarelli (1988). Given that the etymology of elkar and related variants is "hark-har (Mitxelena, 1977), "a combination of the ergative and the absolutive of the distal demonstrative har-» (Trask, 1997, p. 197), Evans concludes that elkar is a good case of «an original binomial anaphor that fused into a single nominal root over time». Thus, the head-like behavior of elkar would be a result of its grammaticalization as a single reciprocal nominal (not a pronoun in Evans's terms, given that it lacks person/number morphology).

Evans (2008) does not mention bata bestea in the explanation of bipartite quantifiers, but the definition squares well with it: the type, «exemplified by English each other and its (rough) equivalents", is usually made up of an initial element meaning either 'each', 'one' or 'other', plus a second 'alterity' or equivalence expression meaning 'other' or 'some such' (Evans, 2008, p. 46). He then goes on to state that equivalents to English each other/one another are found in many European languages, "possibly as a result of widespread calquing into these languages from bible translations» (p. 47). Evans mentions Russian, French, Italian, Spanish, Greek and Finnish among the languages having a bipartite NP anaphor of the each other type. He also asserts that there are related issues to the morphosyntax of the bipartite NPs that may give rise to a further subdivision of the type: there is the question of whether the two members may have a different case marking, the possibility of gender/number inflection depending on the participant group, the degree of cohesion or independence of the two NPs, which may result into a single form $(e . g$. Dutch elkaar, generally considered a reciprocal pronoun altogether).

As the reader can easily check, the makeup of bata bestea fits the structure perfectly: the first part is the word bat, sometimes with article and sometimes without, bearing ergative case if the antecedent is so marked and the second is beste 'other' with the article inflected for the relevant case. Furthermore, as I will show in section 4.1, the bipartite NP has undergone grammaticalization and become a single word in some varieties of Basque, in which case the ergative case may be missing in the first part of the anaphor; finally, it can be safely said that Leizarraga's translation of the New Testament (1571) is the first systematic use of bata bestea (the variant bata berzea with more than 30 examples). To sum up, with respect to Evans's typological approach, the reciprocal anaphors elkar and bata bestea are quite prototypical of the argument marking strategy attested crosslinguistically, with the suggestion that the second anaphor possibly arose across Europe influenced by the translation of the Bible. As we will see in section 5, the history and distribution of bata bestea seems to back up, at least not to disconfirm, that suggestion.

In the generative tradition, there has been a tendency to group reflexive and reciprocal expressions together. However, even though the existence of local versus long-distance reflexives seems quite robust $(e . g$. Dutch zich and zichself), the existence of long-distance reciprocals is at best questionable (Everaert, 2000, 2005, 2008). Reflexives vary between local and long-distance reflexives but no such distinction is apparent for reciprocals with a few problematic languages like Urdu/Hindi, Marathi, Hausa, the last two of which seem to admit long distance reciprocal binding in 
non-finite clauses ${ }^{5}$. In any event, Everaert (2008) stresses that a close attention should be paid to the morphological makeup of the reciprocals crosslinguistically before the issue is settled. This article is a step in that direction.

Another generative work that mentions a suggestive classification of reciprocal structures is Siloni (2012), who argues that, in addition to periphrastic reciprocal constructions and lexical reciprocal verbs, there is a third type, namely structures that express reciprocity as a result of a syntactic process, a type instantiated by Romance and some Slavic languages. Siloni, who works in a lexicalist framework that distinguishes between lexical and syntactic reciprocalization, argues that syntactic reciprocal verbs have a series of properties that set them aside from lexical reciprocal verbs (the latter are truly symmetrical but the syntactic counterparts are not; productivity vs lack thereof; the availability vs unavailability of reciprocal ECM verbs; whether the verb allows the so-called discontinuous construction, only possible for the syntactically constructed reciprocal verbs; the possible derivation of reciprocal event nominals versus lack of them in syntactic reciprocal verbs, and so on). As far I can see, both elkar and bata bestea qualify as periphrastic reciprocal constructions for Saloni and it remains to be determined whether the detransitivization strategy mentioned in section 2 should be considered lexical or syntactic, on a par with the Romance $s e$-reciprocalization ${ }^{6}$.

Once we have provided a crosslinguistic and typological context to understand the nature of the two Basque reciprocal anaphors bata bestea and elkar, I now turn to the different analyses of bata bestea in comparison to elkar.

\section{PREVIOUS TREATMENTS OF BATA BESTEA}

In this section, I review the previous approaches to the anaphor bata bestea throughtout Basque grammar in section 4.1; given the importance of Rebuschi's work, I review these in a separate section 4.2. As it will become clear, there is some discrepancy as to what

5 In principle neither elkar nor bata bestea qualify for long distance reciprocals in this sense:

(i) *Miren-ek eta Jone-k ni-ri utzi didate [elkarr-entzat / bat-a-k beste-a-rentzat lan egiten] Miren-ERG and Jone-ERG I-DAT let AUX elkar-for one-ART-ERG other-ART-for work doing

'Miren and Jon let me work for each other'

This was already pointed out by Rebuschi (1993).

6 If I understand Siloni's account correctly, the Basque reciprocalization strategy by detransitivization appears to be lexical on some counts: first it is lexically restricted to certain verbs (Etxepare, 2003); second, in examples like this:

(i) Jone eta Miren bost biderrez muxukatu dira

Jone and Miren five times kiss AUX

'Jone and Miren kissed five times'

the only possible interpretation is that there were five acts of mutual kissing, not that they each kissed the other five times with the possibility of ten actions of kissing (cfr. Jean et Marie se sont embrassés cinq fois, where both interpretations are available according to Siloni). However, it is true that other features suggest just the opposite: $e . g$. the lack of a discontinous construction. I leave this issue for future research. 
the exact distribution of bata bestea is in complement position. I will tackle this problem in section 5 .

\subsection{Grammarians other than Rebuschi}

Most Basque grammars have paid little or no attention to the existence of two reciprocal anaphors. As far as I know, in traditional grammars prior to the $20^{\text {th }}$ century only the pronoun elkar (or any of its variants) is mentioned; this is the case, for example, of Gèze (1873) and Ithurry (1895). Once in the $20^{\text {th }}$ century, neither Azkue (1923), nor Txillardegi (1978), nor Goenaga (1980), nor Salaburu in his series of articles on binding theory (Salaburu, 1985, 1986a, 1986b), nor Saltarelli (1988) devote a single line to bata bestea, even though their description of elkar is fairly accurate and detailed. Lafitte (1962) is one of the few that draws the attention to the fact that there exists another reciprocal anaphor besides elgar (i. e. the variant of elkar for the dialects he describes): «La reciprocite est plus lourdement traduite par bata... bertzea, l'un... l'autre; batzuek... bertzeak, les uns... les autres» (Lafitte, 1962, p. 95):

$$
\begin{aligned}
& \text { Bat-a-k bertze-a laguntzen dute } \\
& \text { one-ART-ERG other-ART help AUX } \\
& \text { 'They help one another' } \\
& \text { Batzu-ek bertze-ri eman zuten esku } \\
& \text { some-ERG.PL other-DAT give AUX hand } \\
& \text { 'Some shooks hands with the others' }
\end{aligned}
$$

In this article I will not deal with (21) where we find an alleged plural version of bata bestea; instead, I simply focus on reciprocal expressions like bata(k) bestea or bertzea, a bipartite anaphor in Evans's terms.

Villasante (1980, p. 158-9) is one of the few authors that mentions the coexistence of two reciprocal anaphors in Basque in passing, but he gives no examples with bata bestea and implies that the two anaphors are equivalent. Leaving Rebuschi aside for the time being, Euskaltzaindia $(1985,1993)$ is one of the few attempts to clarify matters between the two anaphors: Euskaltzaindia (1985, p. 64) specifies that the genitive form of bata bestea is preferred over the one of elkar in the case of simple nouns like ohe 'bed' and stresses that in general bata bestea can used on a par with elkar. A similar point is made in Euskaltzaindia (1993, p. 69): the genitive form of the anaphor bata bestea will prevail over that of elkar as possessor of a commoun noun; other than that, the two anaphors are regarded as equivalent:

(22) a. Peru-k eta Miren-ek \{bat-a-k beste-a-ren, *elkar-ren\} etxe-a Peru-ERG and Miren-ERG one-ART-ERG other-ART-GEN elkar-GEN house-ART erre dute burn AUX

'Peru and Miren burned each other's house' (EGLA, p. 69) 


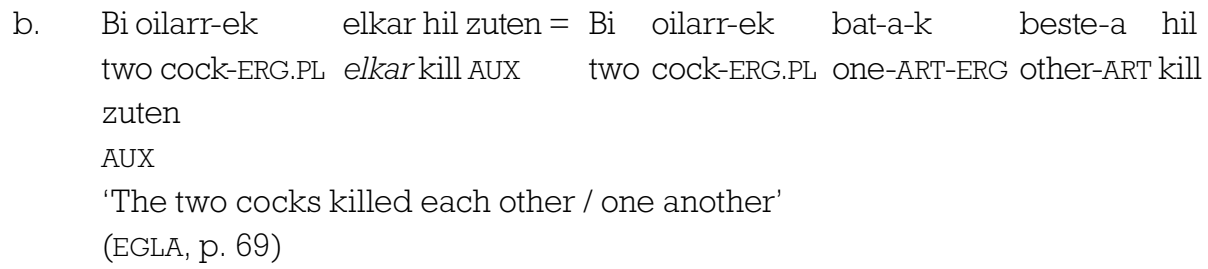

So, it would seem that the distribution of bata bestea is in fact wider than that of elkar ${ }^{7}$.

In the Basque General Dictionary (1987-2011), there are a few notes on the reciprocal anaphor bata bestea under the entry of bat 'one', which can be summarized as follows:

a. this anaphor is taken as a synonym of elkar, and it is presented with two variants, batak bestea /bata bestea and batek bestea/ bat bestea, in competition with each other depending on the presence of the definite article in the first part of the anaphor; the anaphor bears ergative case in both cases if the antecedent is a subject marked ergative;

b. the dictionary suggests that the sequence of the numeral bat followed by the word beste has a syntactic unity as an anaphor, inasmuch as the correlative interpretations where they designate two separate DPs are left out of the defintion: «se incluyen las construcciones batak bestea ikusi, batak besteari eman... (equivalentes a elkar, elkarri), con un sujeto plural, no, obviamente, las del tipo batak bestea ikusi du, batak besteari eman dio)»;

c. it is mentioned that the reciprocal anaphor batak bestea is scarcely used in all dialects. It is not clear whether this refers to the overall use of the anaphor or to the anaphor bearing ergative case. In view of the great amount of examples with elkar and its variants across all dialects, it seems that the first one is the intended meaning.

Artiagoitia (2003) is a description of Basque reciprocal expressions and it has a separate section on bata bestea. The section contains a short morphological description of the anaphor, as well as a few remarks on its distribution and interpretation. With respect to interpretative nuances, Artiagoitia (2003) remarks that some restrictions on the use of bata bestea are purely semantic, not syntactic. Thus, the following contrast is more apparent than real:

\footnotetext{
7 However, the DGV states that older Northern writers and, presently, Southern writers have a few examples with elkarren as true possessor or subject inside noun phrases:

(i) Bi lagun-ek alkarr-en arnasa nabari [zuten] two friend-PL.ERG elkar-GEN breath.ART sense AUX

'The two friends felt each other's breath' (Anabitarte, Poli, 1958, 105)

The same point is made by De Rijk (2008, p. 370), who claims that there are two uses (systems) of elkar: for some speakers (the broad system) it is an exact equivalent of bata bestea in distributional terms; for others, elkarren is excluded as a true possessor (the narrow system).
} 
(23) \{elkarr-ekin, *bat-a beste-a-rekin\} joango gara

elkar-with one-ART other-ART-with go AUX

'We shall go \{together, *with each other'\}

(adapted from HEE, 1994, p. 177)

Though it seems rather bad to use bata bestea due to the lack of reciprocal or symmetrical interpretation of the predicate at hand, Artiagoitia holds that there is no restriction on using bata bestea with the commitative, provided a clear reciprocal interpretation is available:

(24) Gu bat-a beste-a-rekin haserretu gara we one-ART other-ART-with get angry AUX

'We got angry with each other'

Artiagoitia (2003) also mentions that, unlike elkar, bata bestea occasionally permits long-clausal binding within an embedded subject, but not otherwise; this was originally suggested by HEE (1994) for Lekeitio Basque:

(25) a. Epi-k eta Blas-ek uste dute bat-a beste-a-ren jostailu-ak polit-ak

Epi-ERG and Blas-ERG think AUX one-ART other-ART-GEN toy-ART pretty- ART dir-ela

are-that

'Ernie and Bert think that each other's toys are fun'

(Artiagoitia, 2003, p. 613)

b. * Fernandez-ek eta Clemente-k Alaves-ek bat-a-k beste-a-ren

Fernandez-ERG and Clemente-ERG Alaves-ERG one-ART-ERG other-ART-GEN talde-a-ri irabaziko dio-la iragarri dute.

team-ART-DAT win AUX-that announce AUX

'Luis Fernandez and Clemente announced that Alaves would beat each other's team'

(Artiagoitia, 2000, p. 293)

Finally, De Rijk (2008) also mentions both reciprocal anaphors separately and terms them synthetic and analytic respectively; he further assumes that they are for most part equivalent. In his description De Rijk reiterates the idea that the possessive form of elkar is restricted to relational and location nouns for most speakers, even though some speakers seem to tolerate it with other nouns. As a corollary, De Rijk draws a distinction between the two variants of bata bestea, depending on whether the first element of the anaphor bears ergative case or not (when bound by an ergative subject):

(26) a. Guraso-ek bat-a beste-a maite dute parents-ERG.Pl one-ART other-ART love AUX

b. Guraso-ek bat-a-k beste-a maite dute parents-ERG.PL one-ART-ERG other-ART love AUX 'parents love one another' (De Rijk, 2008, p. 37l) 
He terms the second variant of the anaphor pseudo-reciprocal, implying that the variant without case-marking on the first member is the true, lexicalized, reciprocal anaphor. This description also paves the way to look into a possible syntactic variation in the use of this anaphor.

In short, what grammarians have said about elkar and bata bestea can be summarized as follows:

a. bata bestea is a two-phrase or bipartite reciprocal anaphor with a plural antecedent;

b. most grammars assert that elkar and bata bestea can be used in a similar way;

c. bata bestea has a wider distribution than elkar in that the latter is excluded from cross-clausal binding and in that it is also excluded for many speakers from the true possessor's position ( $c f r$. footnote 7 );

d. for interpretive or semantic reasons yet to be spelled out, both anaphors cannot co-occur in certain contexts and, in those cases, either one or the other is used;

e. bata bestea has a form marked ergative on the first part of the anaphor when bound by an ergative subject but the use of this variant is apparently not universal;

f. there is some variation in the configuration of the first part of bata bestea, given that it sometimes appears with the article and sometimes it does not.

\subsection{Rebuschi's account of the distinction between elkar and bata bestea}

Rebuschi takes all the credit for having studied thoroughly the different distribution patterns of Basque anaphors (both reflexive and reciprocal) with special attention to the Navarro-Labourdin dialect in a series of articles (Rebuschi, 1988, 1989, 1992, 1993). In the first two he departs from Chomsky's $(1981,1986)$ classical version of Binding Theory, according to which both types of anaphors (reflexives like bere burua and reciprocals like elkar) must obey Principle A:

\section{Principle A: anaphors must be bound in their local domain}

In the eighties, binding entailed coindexing and c-commanding by the antecendent; the reference of the anaphor was supposed to be provided by a local c-commanding antecedent. The notion of local domain captured the idea that antecedent and anaphor must be at a certain distance, the same sentence in the regular case. Let us take the following two examples:

(28) a. Gu-re lagun-ek $\mathrm{k}_{\mathrm{j}}$ elkarr- $\mathrm{i}_{*_{\mathrm{i}} \mathrm{j}}$ sekretu-a kontatu diote we-GEN friend-ERG.PL elkar-DAT secret-ART tell AUX

'Our friends told the secret to each other'

b. Jokalari-ek $\mathrm{i}_{\mathrm{i}}$ ondo dakite [presidente-a-k eta entrenatzaile-a-k] player-ERG.PL well know president-ART-ERG and coach-ART-ERG elkarr-ekin ${ }_{*_{i} / j}$ afaldu dute-la. elkar-with dine AUX-that

'The players know well that the president and the coach had dinner together (lit: with one another)' 
In (28a), elkar takes reference from the subject gure lagunek and not from the possessive gure; i. e., interpreting reciprocity in a loose way, the sentence means something like «friends related to us have told a secret to each other", and not «"friends related to us have spread a secret among all of us». This is a direct consequence of the subject's c-commanding elkar, a relation which does not obtain for gure. In (28b) we understand that the reference of elkarrekin depends on the president and the coach, the sentence cannot mean that each one of the players know the president and the coach had dinner with some other player; in other words, elkar cannot pick the main subject as its antecedent, it is bound to pick its antecedent clause-internally.

Rebuschi $(1988,1989)$ criticizes Chomsky's rigid definition of local domain and defends that two domains must be differentiated for each pronominal or anaphoric expression:

\author{
Narrow Binding Domain (NBD) \\ A given XP is a rigid binding domain for a given expression if it contains that \\ expression and a subject \\ Wide Binding Domain (WBD) \\ A given XP is a wide binding domain for a given expression if it contains that \\ expression and a c-commanding subject
}

Each pronoun may have separate binding conditions for the two domains; in fact, Rebuschi relies on this to account for the difference between elkar and bata bestea reported in the previous section ${ }^{8}$ :

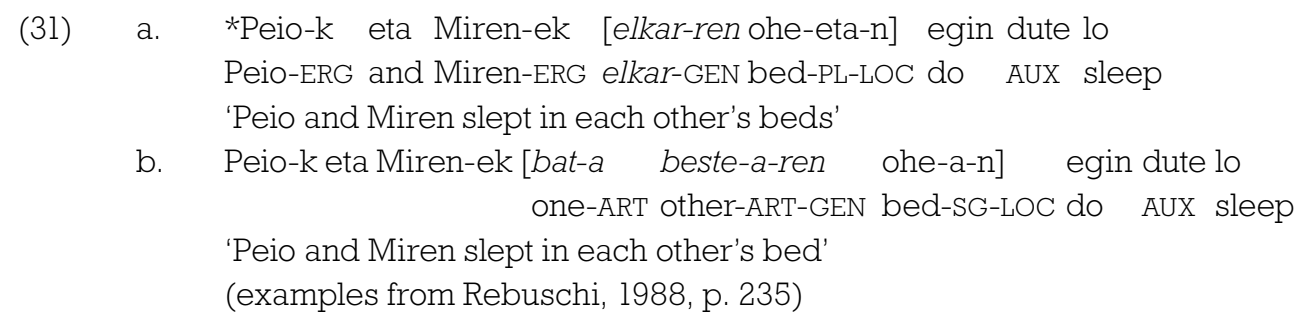

In these examples, assuming that the possessor is some kind of subject, the bracketed constituent counts as the NBD, given that it contains the anaphor under scrutiny and a subject (the anaphor itself), but it would be the entire sentence the one that counts as the WBD, given that one must get up to IP/TP to get a subject which c-commands the anaphor (i.e. the matrix subject Peio and Miren). Therefore, the different distribution of the two reciprocal anaphors can be accounted for in the following way:

8 Rebuschi always reports his data using the ergative-less variant of bata bestea; i. e. the grammaticalized version, not the pseudo-reciprocal in De Rijk's (2008) terms. 

a. Elkar must be bound in its NBD and in its WBD
b. Bata bestea must be bound in its WBD (not necessarily so in its NBD) (adapted from Rebuschi, 1988, p. 237)

In example (31a), elkar is bound in its NBD but not in its WBD, as it should; bata bestea in (31b), on the other hand, is bound in its NBD and free in its WBD, and nothing hinges on this given that it must be bound only in the narrower domain. The direct consequence of (32) is that elkar is limited to object positions and cannot show up in subject positions; bata bestea, however, does not have that limitation and can show up both in object and subject positions. Therefore, we expect the two reciprocal anaphors to co-occur in many (generally object) positions:

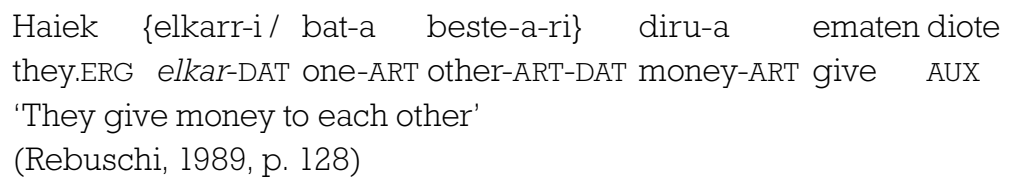

Here the dative is presumably an argument of the ditransitive verb $\operatorname{eman}^{9}$, and the sentence is both the WBD and the NBD.

Rebuschi (1993) changes the approach to the difference between the two reciprocals and, based on the difference between the reflexive anaphors bere burua and bere, he ends up proposing that elkar must be bound in its NBD and bata bestea must be free precisely in the same domain:

(34) a. Elkar must be bound in both the NBD and the WBD

b. Bata bestea must be free in the NBD and bound in its WBD

(Rebuschi, 1993, p. 136)

In the new approach, the definition of binding domain follows Koster $(1985,1987)$ without the need of mentioning the notion of subject in both cases:

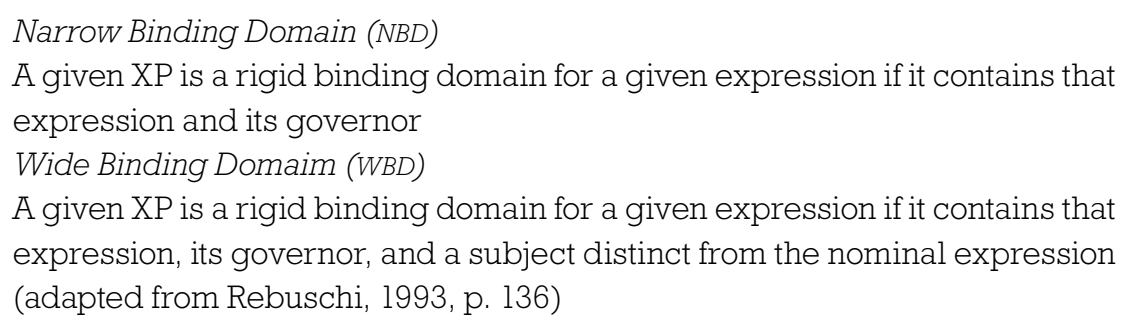

9 The relation dative-verbal projections may be mediated by applicative heads; see Ormazabal and Romero (2010) and Oyharçabal (2010) for two different views. 
The concept of governor is not used any more in generative syntax, but we could tentatively say that the closest $\mathrm{V}, \mathrm{Adj}, \mathrm{N}$ or Postposition containing the pronoun would count as governor.

The crucial point here is that this re-definition of binding domains has the effect of changing the predictions on the distribution of the two reciprocal anaphors: in fact, if Rebuschi (1993) is right, the asymmetrical distribution of both should extend to more contexts, given that they have contradictory binding characteristics for the smaller NBD. Here are Rebuschi's own data:

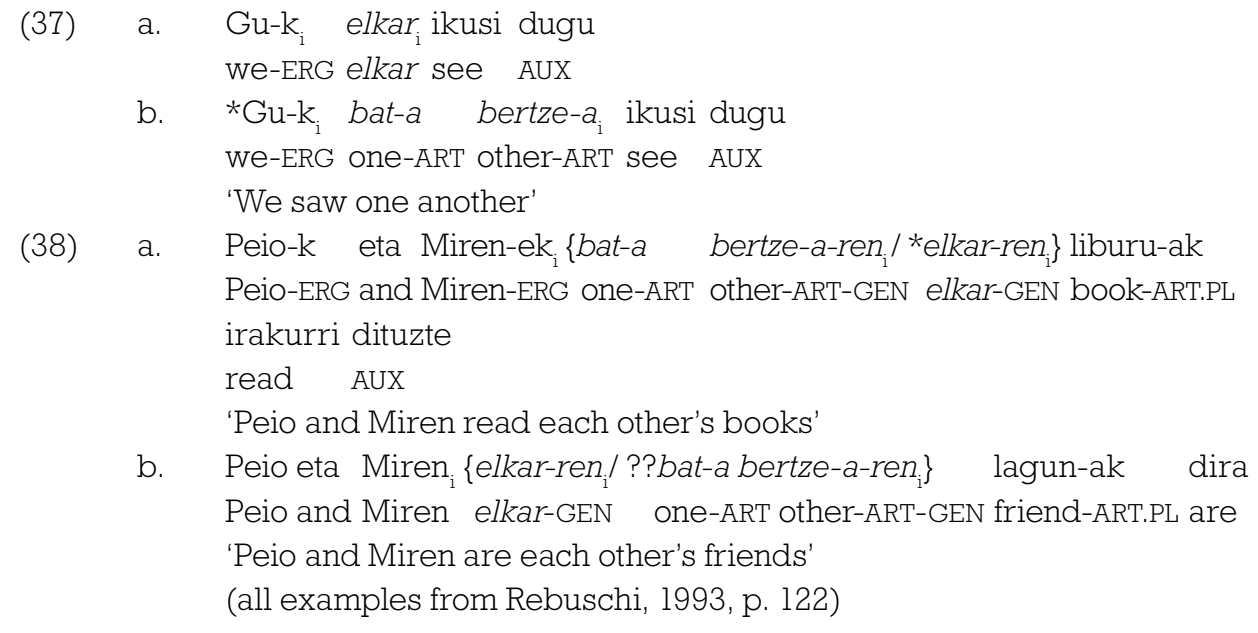

Contrary to his (i.e. Rebuschi, 1988, 1989) previous claims, now it is predicted that bata bestea (but not elkar) will be excluded from the object position of verbs. That will be so whether we take VP or TP as the relevant NBD. For the second pair of examples he foresees a complementary distribution similar to that of his previous account: in (38a) the bracketed DP [X-en liburuak] counts as the NBD and there elkar is not bound but bata bestea is free, as required. These genitives are in principle not complements, but some kind of possessors, and the noun or the determiner would count as their governor. In any case, the explanation of this minimal pair remains practically the same as in (Rebuschi, 1988, 1989). However, regarding example (38b), Rebuschi assumes that is a predicate nominal with a PRO subject inside:

$$
\text { Peio eta } \text { Miren }_{\mathrm{i}}\left[\mathrm{PRO}_{\mathrm{I}}\left\{\text { elkarren }_{\mathrm{i}} / \text { ? ? bata bertzearen } \mathrm{i}_{\mathrm{i}}\right\}\right. \text { lagunak] dira }
$$

This way, the bracketed structure becomes the NBD and elkar must be bound there (which is the case) but bata bestea must be free, contrary to fact; hence the second reciprocal gives rise to an ungrammatical sentence. In short, Rebuschi's new account predicts that the reciprocal anaphor bata bestea will now be excluded from the object position of both verbs and nouns. 
Without getting into too much detail, the refinement of the account makes two clear predictions:

1. bata bestea will not appear in the complement position of verbs;

2. bata bestea will not appear in the complement position of relational nouns ${ }^{10}$.

\section{REBUSCHI'S DILEMMA'S RESOLUTION: BATA BESTEA IN THE BASQUE LITERARY TRADITION}

Having summarized the behavior of the reciprocal anaphor bata bestea, we will discuss how, in which syntactic environments, and with which morphological shape this reciprocal anaphor shows up in the literary tradition in the following sections 5.1. and 5.2; section 5.3 will discuss to what extent Rebuschi's expectations are fulfilled for the Navarro-Labourdin dialect and for other dialects. I leave the study of further differences between elkar and bata bestea for section 6 .

\subsection{The anaphor bata bestea: when and how it is found}

As the Basque General Dictionary explains, there are two traditions when it comes to this bipartite reciprocal anaphor. On the one hand, some writers use the definite form of the numeral bat and this gives rise to the forms bata(k) bestea, bata(k) bertzea, depending on which variant of the word for alterity is used (beste-a or bertze-a); in the case of the latter, the article is always used. Tables 1.1 and 1.2 provide the relevant summary for each of the variants, distinguishing two periods $\left(16^{\text {th }}-18^{\text {th }}\right.$ and $\left.19^{\text {th }}-20^{\text {th }}\right)$.

10 There are in fact further complications, as Rebuschi (1993) is forced to make contradictory assumptions regarding all the cases where elkar and bata bestea do in fact co-occur (e. g. in dative complements and inside locative phrases within perception complements). See Urrutia, Goitia and Artiagoitia (2013) on this. 
Table 1.1. Writers' usage of bata bestea, $16^{\text {th }}-18^{\text {th }}$ centuries

\begin{tabular}{|c|c|c|c|c|}
\hline Century & Writer & Dialect & bata ber $(t) z e a$ & bata bestea \\
\hline \multirow{2}{*}{$16^{\text {th }}$} & Etxepare & $\mathrm{NL}$ & $\mathrm{x}$ & \\
\hline & Leizarraga & $\mathrm{NL}$ & $\mathrm{x}$ & \\
\hline \multirow{12}{*}{$17^{\text {th }}$} & Aranbillaga & $\mathrm{NL}$ & $\mathrm{x}$ & \\
\hline & Argainaratz & $\mathrm{NL}$ & $\mathrm{x}$ & \\
\hline & Axular & $\mathrm{NL}$ & $\mathrm{x}$ & \\
\hline & Belapeire & $\mathrm{S}$ & & $\mathrm{x}$ \\
\hline & Beriain & $\mathrm{N}$ & $\mathrm{x}$ & \\
\hline & Etxeberri Dorre & $\mathrm{NL}$ & $\mathrm{x}$ & \\
\hline & Etxeberri of Ziburu & NL & $\mathrm{x}$ & \\
\hline & Gazteluzar & $\mathrm{NL}$ & $\mathrm{x}$ & \\
\hline & Haranburu & $\mathrm{NL}$ & $\mathrm{x}$ & \\
\hline & Materra & $\mathrm{NL}$ & $\mathrm{x}$ & \\
\hline & Pouvreau & NL & $\mathrm{x}$ & \\
\hline & Tartas & S & $\mathrm{x}$ & \\
\hline \multirow{12}{*}{$18^{\text {th }}$} & Egiategi & S & $\mathrm{x}$ & \\
\hline & Etxeberri of Sara & $\mathrm{NL}$ & $\mathrm{x}$ & \\
\hline & Haraneder & NL & $\mathrm{x}$ & \\
\hline & Kardaberaz & $\mathrm{C}$ & & $\mathrm{x}$ \\
\hline & Larramendi & $\mathrm{C}$ & & $\mathrm{x}$ \\
\hline & Larregi & $\mathrm{NL}$ & $\mathrm{x}$ & \\
\hline & Maister & $\mathrm{S}$ & & $\mathrm{x}$ \\
\hline & Mendiburu & $\mathrm{N}$ & & $\mathrm{x}$ \\
\hline & Mihura & $\mathrm{NL}$ & $\mathrm{x}$ & \\
\hline & Otxoa de Arin & $\mathrm{C}$ & & $\mathrm{x}$ \\
\hline & Ubillos & $\mathrm{C}$ & & $\mathrm{x}$ \\
\hline & Xurio & NL & $\mathrm{x}$ & \\
\hline
\end{tabular}

Here is a typical example from Mirande with ergative case-marking for the first member of the anaphor:

(39) Arrats-ez, lane-tik ateratze-a-n, bat-a-k beste-a igurikitzen zuten afternoon-INST work-from leave-ART-LOC one-ART-ERG other-ART await AUX 'In the afternoon, upon getting out of work, they awaited each other' (Mirande, Idazlan Hautatuak, 1970, p. 146) 
Table 1.2. Writers' usage of bata bestea, $19^{\text {th }}-20^{\text {th }}$ centuries

\begin{tabular}{|c|c|c|c|c|}
\hline Century & Writer & Dialect & bata ber $(t) z e a$ & bata bestea \\
\hline \multirow{22}{*}{$19^{\text {th }}$} & Agirre, Tx. & $\mathrm{W}$ & & $\mathrm{x}$ \\
\hline & Alzaga & $\mathrm{C}$ & & $\mathrm{x}$ \\
\hline & Añibarro & $\mathrm{W}$ & & $\mathrm{x}$ \\
\hline & Arana, J.I. & $\mathrm{C}$ & & $\mathrm{x}$ \\
\hline & Arbelbide & $\mathrm{NL}$ & $\mathrm{x}$ & \\
\hline & Astarloa & $\mathrm{W}$ & & $\mathrm{x}$ \\
\hline & Azkue, E. & W & & $\mathrm{x}$ \\
\hline & Duhalde & $\mathrm{NL}$ & $\mathrm{x}$ & \\
\hline & Duvoisin & $\mathrm{NL}$ & $\mathrm{x}$ & \\
\hline & Frai Bartolome & $\mathrm{W}$ & & $\mathrm{x}$ \\
\hline & Gerriko & $\mathrm{C}$ & & $\mathrm{x}$ \\
\hline & Goyhetche & $\mathrm{NL}$ & $\mathrm{x}$ & \\
\hline & Iturriaga & $\mathrm{C}$ & & $\mathrm{x}$ \\
\hline & Iturzaeta & $\mathrm{W}$ & & $\mathrm{x}$ \\
\hline & Iztueta & $\mathrm{C}$ & & $\mathrm{x}$ \\
\hline & Laphitz & NL & $\mathrm{x}$ & \\
\hline & Lardizabal & $\mathrm{C}$ & & $\mathrm{x}$ \\
\hline & Legaz & $\mathrm{N}$ & $\mathrm{x}$ & \\
\hline & Lizarraga & $\mathrm{N}$ & $\mathrm{x}$ & 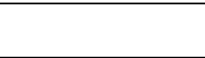 \\
\hline & Mogel, J. A. & W & & $\mathrm{x}$ \\
\hline & Uriarte & W, C & & $\mathrm{x}$ \\
\hline & Zavala, J. M. & $\mathrm{W}$ & & $\mathrm{x}$ \\
\hline \multirow{13}{*}{$20^{\text {th }}$} & Agirre, Tx. & W, C & & $\mathrm{x}$ \\
\hline & Agirre, T. & $\mathrm{C}$ & & $\mathrm{x}$ \\
\hline & Anabitarte & $\mathrm{C}$ & & $\mathrm{x}$ \\
\hline & Arrese Beitia & $\mathrm{W}$ & & $\mathrm{x}$ \\
\hline & Atxaga, M. & $\mathrm{C}$ & & $\mathrm{x}$ \\
\hline & Berrondo & $\mathrm{C}$ & & $\mathrm{x}$ \\
\hline & Dihartze & NL & $\mathrm{x}$ & $\mathrm{x}$ \\
\hline & Eguzkitza, J.B. & $\mathrm{W}$ & & $\mathrm{x}$ \\
\hline & Enbeita, B. & $\mathrm{W}$ & & $\mathrm{x}$ \\
\hline & Enbeita, K. & $\mathrm{W}$ & & $\mathrm{x}$ \\
\hline & Erkiaga & $\mathrm{W}, \mathrm{C}$ & & $\mathrm{x}$ \\
\hline & Etxaniz & $\mathrm{C}$ & & $\mathrm{x}$ \\
\hline & Etxeita & $\mathrm{W}$ & & $\mathrm{x}$ \\
\hline
\end{tabular}




\begin{tabular}{|c|c|c|c|c|}
\hline Century & Writer & Dialect & bata ber $(t) z e a$ & bata bestea \\
\hline \multirow{17}{*}{$20^{\text {th }}$} & Goikoetxea Gaztelu & $\mathrm{C}$ & & $\mathrm{x}$ \\
\hline & Inza & $\mathrm{C}, \mathrm{N}$ & & $\mathrm{x}$ \\
\hline & Irazusta & $\mathrm{C}$ & & $\mathrm{x}$ \\
\hline & Kirikiño & $\mathrm{W}$ & & $\mathrm{x}$ \\
\hline & Lizardi & $\mathrm{C}$ & & $\mathrm{x}$ \\
\hline & Mirande & SB & & $\mathrm{x}$ \\
\hline & Mitxelena, K. & $\mathrm{C}, \mathrm{SB}$ & & $\mathrm{x}$ \\
\hline & Mujika, P. & $\mathrm{C}$ & & $\mathrm{x}$ \\
\hline & Munita & $\mathrm{C}$ & & $\mathrm{x}$ \\
\hline & Orixe & $\mathrm{C}$ & & $\mathrm{x}$ \\
\hline & Otxolua & $\mathrm{W}$ & & $\mathrm{x}$ \\
\hline & Salaberria & $\mathrm{C}$ & & $\mathrm{x}$ \\
\hline & Txirrita & $\mathrm{C}$ & & $\mathrm{x}$ \\
\hline & Ugalde & $\mathrm{C}$ & & $\mathrm{x}$ \\
\hline & Urruzuno & $\mathrm{C}$ & & $\mathrm{x}$ \\
\hline & Uztapide & $\mathrm{C}$ & & $\mathrm{x}$ \\
\hline & Villasante & $\mathrm{C}$ & & $\mathrm{x}$ \\
\hline
\end{tabular}

Far fewer writers, on the other hand, use the bare numeral bat without the article, and this gives rise to the forms bat(ek) bestea and bat(ek) bertzea, with the word 'other' (whether bertze or beste) always displaying the article. Etienne Salaberry is a good example of this tendency:

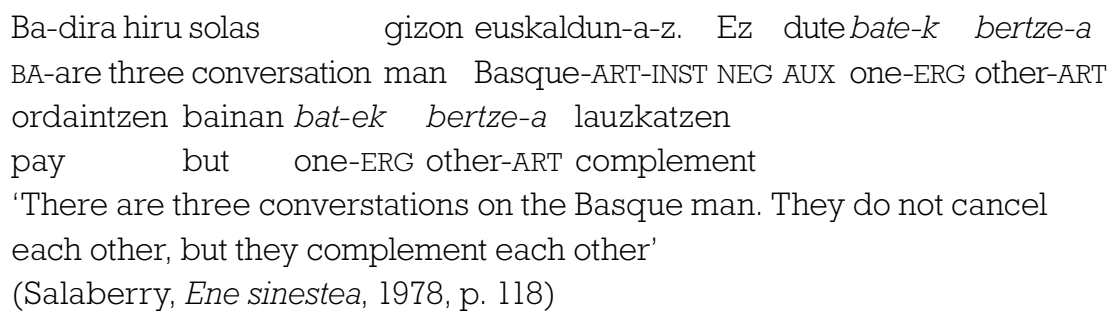

Table 2 summarizes the practice by authors who use these article-less variants; the first occurrences are sporadic during the $17^{\text {th }}$ and $18^{\text {th }}$ century. 
Table 2. Writers' usage of bat bestea \& bat ber(z)ea

\begin{tabular}{|c|c|c|c|c|c|c|}
\hline \multirow[t]{2}{*}{ Century } & \multirow[t]{2}{*}{ Writer } & \multicolumn{2}{|c|}{ bat ber $(t) z e a$} & \multicolumn{2}{|c|}{ bat bestea } & \multirow[t]{2}{*}{ Dialect } \\
\hline & & Systematic & Sporadic & Systematic & Sporadic & \\
\hline $17^{\text {th }}$ & Tartas & & 1 example & & & $S$ \\
\hline \multirow{3}{*}{$18^{\text {th }}$} & Egiategi & & 1 example & & & S \\
\hline & Haraneder & & 1 example & & & NL \\
\hline & Mendiburu & & & & 1 example & $\mathrm{N}$ \\
\hline \multirow{8}{*}{$19^{\text {th }}$} & Arxu & & & $\mathrm{x}$ & & $S$ \\
\hline & Duhalde & & 1 example & & & NL \\
\hline & Etxagarai & & & $\mathrm{x}$ & & $\mathrm{C}$ \\
\hline & Etxamendi Bordel & & & $\mathrm{x}$ & & NL \\
\hline & Hiribarren & $\mathrm{x}$ & & & & $\mathrm{NL}$ \\
\hline & Joanategi & $\mathrm{x}$ & & & & $\mathrm{NL}$ \\
\hline & Laphitz & $\mathrm{x}$ & & & & NL \\
\hline & Zavala & & & $\mathrm{x}$ & & $\mathrm{W}$ \\
\hline \multirow{16}{*}{$20^{\text {th }}$} & Barbier & $\mathrm{x}$ & & & & NL \\
\hline & Elissalde & $\mathrm{x}$ & & & & $\mathrm{NL}$ \\
\hline & Elissanburu, J. B. & $\mathrm{x}$ & & & & NL \\
\hline & Elissanburu, M. & $\mathrm{x}$ & & & & NL \\
\hline & Etxamendi, M. & & & $\mathrm{x}$ & & NL \\
\hline & Etxepare, J. & $\mathrm{x}$ & & & & NL \\
\hline & Etxepare Landerretxe & $\mathrm{x}$ & & & & $\mathrm{NL}$ \\
\hline & Hiriart-Urruty & $\mathrm{x}$ & & & & NL \\
\hline & Larzabal & $\mathrm{x}$ & & & & NL \\
\hline & Mattin Treku & $\mathrm{x}$ & & $\mathrm{x}$ & & NL \\
\hline & Mitxelena, S. & & & & $\mathrm{x}$ & $\mathrm{C}$ \\
\hline & Narbaitz & & & $\mathrm{x}$ & & $\mathrm{NL}$ \\
\hline & Orixe & & & & $\mathrm{x}$ & $\mathrm{C}$ \\
\hline & Oxobi & & $\mathrm{x}$ & & & NL \\
\hline & Uztapide & & & & $\mathrm{x}$ & $\mathrm{C}$ \\
\hline & Xalbador & $\mathrm{x}$ & & & & $\mathrm{NL}$ \\
\hline
\end{tabular}

According to Urrutia, Goitia and Artiagoitia (2013), there is no record of a single author using bat bestea/bertzea in a systematic way up to Laphitz and Hiribarren, both $19^{\text {th }}$ century writers of the Navarro-Labourdin dialect. Thus Etxepare, Leizarraga, Axular, Etxeberri of Ziburu, Pouvreau, Tartas, Egiategi, Etxeberri of Sara, Kardaberaz, Mendiburu, Añibarro, Duvoisin, Lardizabal, J. A. Mogel, all of them prefer the 
articled variant bat- $a$ as the first member of the quantificational anaphor. It seems that the generalization of bat bertzea or bat bestea is relatively new and it is confined to the French Basque Country. On the Spanish side, there are a few examples here and there (S. Mitxelena, Orixe, Uztapide) but not a systematic use.

Putting aside the issue of the presence versus absence of the article in the first member of the bipartite anaphor, it is remarkable that the use of this anaphor is fairly well attested in all kind of authors and dialects from the $16^{\text {th }}$ century on. As expected, the anaphor is generally bound by a plural DP. Here is a couple of examples by Leizarraga:

(41) a. Bada, ene anaieak, biltzen zaretenean iatera batak berzea iguriki ezazue (Leizarraga, 1571, 1 Co 11, 33)

'Well, my brothers, when you gather to eat, you should await for each other'

b. Haur da ene manamendua, batak berzea maite duzuen, nik maite ukhan zaituztedan bezala (Leizarraga, 1571, Jn 15, 12)

'This is my commandment, that you love each other as I have loved you all'

In these examples anaphor batak berzea occurs in object position and bound by a silent pro 'you all', identified by, or recoverably from, the agreement morphology of the finite verb. Similarly, the anaphor may appear as a dative complement:

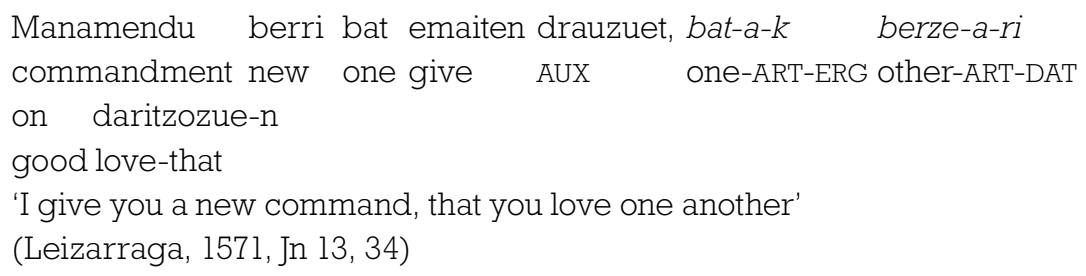

It can also appear as object to postpositions as well, again bound by the main subject:

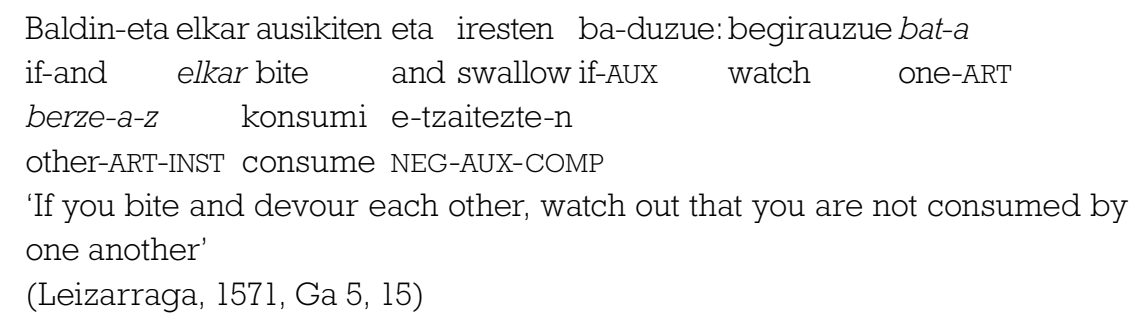

Finally, we find bata bestea in its genitive form, as a true possessor or subject of a common noun $(=44 a)$, and also as a complement to a location noun $(=44 b)$ or to a relational noun $(=44 \mathrm{c})$; I provide some examples by Leizarraga again:

(44) a. Iainkoak...manatzen gaituela elkar onhets dezagun, afekzione onez eta hipokrisia gabe, batak berzearen ona prokura dezagun (Leizarraga, Othoitza ecclesiastikoen forma eta catechismea, 1571, 61) 
'God demands that we love one another, with affection and without hypocrisy, that we seek each other's well-being'

b. Eta hek has zitezen tristetzen: eta hari erraiten bata berzearen ondoan, Ni naiz? (Leizarraga, 1571, Mk 19, 3)

'And they started being upset and saying to him one after another, am I the one?

c. Halaber gazteak, zareten zaharren suiet, eta guziak zareten bata berzearen suiet (Leizarraga, 1571, l P 5, 5)

'You the younger, submit yourselves to the elder, and all of you clothe yourselves with humility toward one another'

In all the three examples, the main subjects ( $g u k$ 'we', hek 'they' and zuek guziak 'you all') are the ones that bind the anaphor. We can regard Leizarraga as the paradigmatic user of bata bestea in that he provides abundant examples. Nevertheless, from Leizarraga on, there are many examples of the use of bata bestea, across the centuries. I have arranged the examples according to syntactic position ${ }^{11}$.

\section{a. Batak bestea in object position:}

(45) a. Ikusazu .... nola bat-a-k bertze-a mesprezatzen dute-n eta see how one-ART-ERG other-ART despise AUX-COMP and

ez-tute-n elkhar maite itxura falso-z eta gezur-mainazbaizen NEG-AUX-COM elkar love appearance false-INST and lie-form but

'See how they despise one another and they do not love each other but with false appearance and lies'

(Pouvreau, San Frances de Sales Genevaco ipizpicuaren Philotea, 1664, 67)

b. Ar zazue ongi bat-a-k beste-a

take AUX well one-ART-ERG other-ART

'Let you all treat one another well'

(Mendiburu, Mendibururen Idazlan Argitaragabeak I, 1982 [1740-1767], p. 205)

c. ... eta etsai-ek bat-a-k bertze-a sarraskitzen zuten and enemy-ERG.PL one-ART-ERG other-ART massacre AUX

'... and enemies massacred one another'

(Duvoisin, Bible Saindua, 1859-1865, Ep 7, 22)

d. Mutil bi-ok, aspalditxoan, ezin zuten bat-a-k beste-a ikusi boy two-ART.ERG lately Can.NEG AUX one-ART-ERG other-ART see 'Lately, the two boys coud not bear each other' (Agirre, Garoa, 1912, p. 272)

\section{b. Bata(k) bestea in dative object position:}

(46) a. Eta halatan guzti-ak bat-a bertze-a-ri zerraitza-la kondenatu ziren and so all-ART.PL one-ART other-ART-DAT follow-that condemn AUX

11 The literature in Western and Central Basque is scarce for the $16^{\text {th }}-17^{\text {th }}$ centuries and there is no single example of bata bestea in it, except for Landucci's dictionary: bata vesteaquin conçertadu ('concordar uno con otro'). 
'And so all were condemned (as they were) following one another' (Axular, Gero, 1643, 166)

b. Ordean bat-a-k bertze-a-ri ematen ziñotzote-n adiskidetasun-a-ren however one-ART-ERG other-ART-DAT give AUX-COMP friendship-ART-GEN señal-ek intres ver-a zuten,Jinko-a-ren loria-ren intres-a signal-ERG.PL interest same-ART had, god-ART-GEN glory-GEN interest-ART 'However, the signals of friendship that you gave to each other had the same interest, the interest of the Lord's glory'

(Mihura, Andredena Mariaren Imitacionea Jesus-Christoren Imitacionearen gañean moldatua, 1778, 67)

c. Mundu-a-n enbidia / bat-a-k beste-a-ri / izaten oi diogu / world-SG-LOC envy one-ART-ERG other-ART-DAT have PART AUX txit maiz edo beti very often or always

'In this world, very often or always, we feel envy toward one another' (Iturriaga, Fábulas y otras composiciones en verso vascongado, 1842, 12)

d. bizkarr-a itzultzen dute, jalgitze-a-rekin, bat-ek bertze-a-ri back-ART turn AUX exit-ART-with one-ERG other-ART-DAT 'Upon getting out, they turn their backs on each other' (Jean Etxepare, Buruxkak, 1910, 170)

\section{c. Bata bestea as complement to adpositions:}

(47) a. Aitzitik ba-dirudi, ezen bertze hitzkuntza, eta lenguaia on the contrary BA-seem that other language and speech guzti-ak bat-a bertze-a-rekin nahasi-ak dire-la all-ART.PL one-ART other-ART-with mix-ART.PL are-that 'On the contrary, it seems that all other speeches and languages are mixed up with one another'

(Etxeberri of Sara, Obras vascongadas del doctor labortano Joannes d'Etcheberri (1712), 1908 [1712-1718], 93)

b. Ikhusten duk, Pello, ... Sara-k eta Zugarramurdi-k amodio guti behar see AUX Pello Sare-ERG and Zugarramurdi-ERG love little must zute-la izan bat-ek bertze-a-rentzat AUX-that have one-ERG other-ART-for 'You can see, Pello, ... that Sare and Zugarramurdi must have had little love for each other'

(Elissanburu, Piarres Adame, 1889, 73)

c. ... ez omen ditugu fonetika eta grafia, adibide-z, bat-a beste-tik NEG PRT AUX phonetics and ortograpy example-INST one-ART other-from edo bat-a beste-a-rengandik bereizten. or one-ART other-ART-from distinguish 'We apparently do not distinguish phonetics and orthography from each other or apart from one another' (Mitxelena, Mitxelenaren Euskarazko Idazlan Guztiak VII, 1988, 171) 


\section{d. Bata bestea in the genitive:}

Here I repeat the three positions mentioned before, that is: true possesor or subject genitive $(=48 \mathrm{~b})$, complement to a location noun or an adposition, $(=48 \mathrm{a}-\mathrm{d})$ and complement to a relational noun $(=48 \mathrm{c})$. It is true, however, that after Leizarraga the most usual occurrence is the second option:

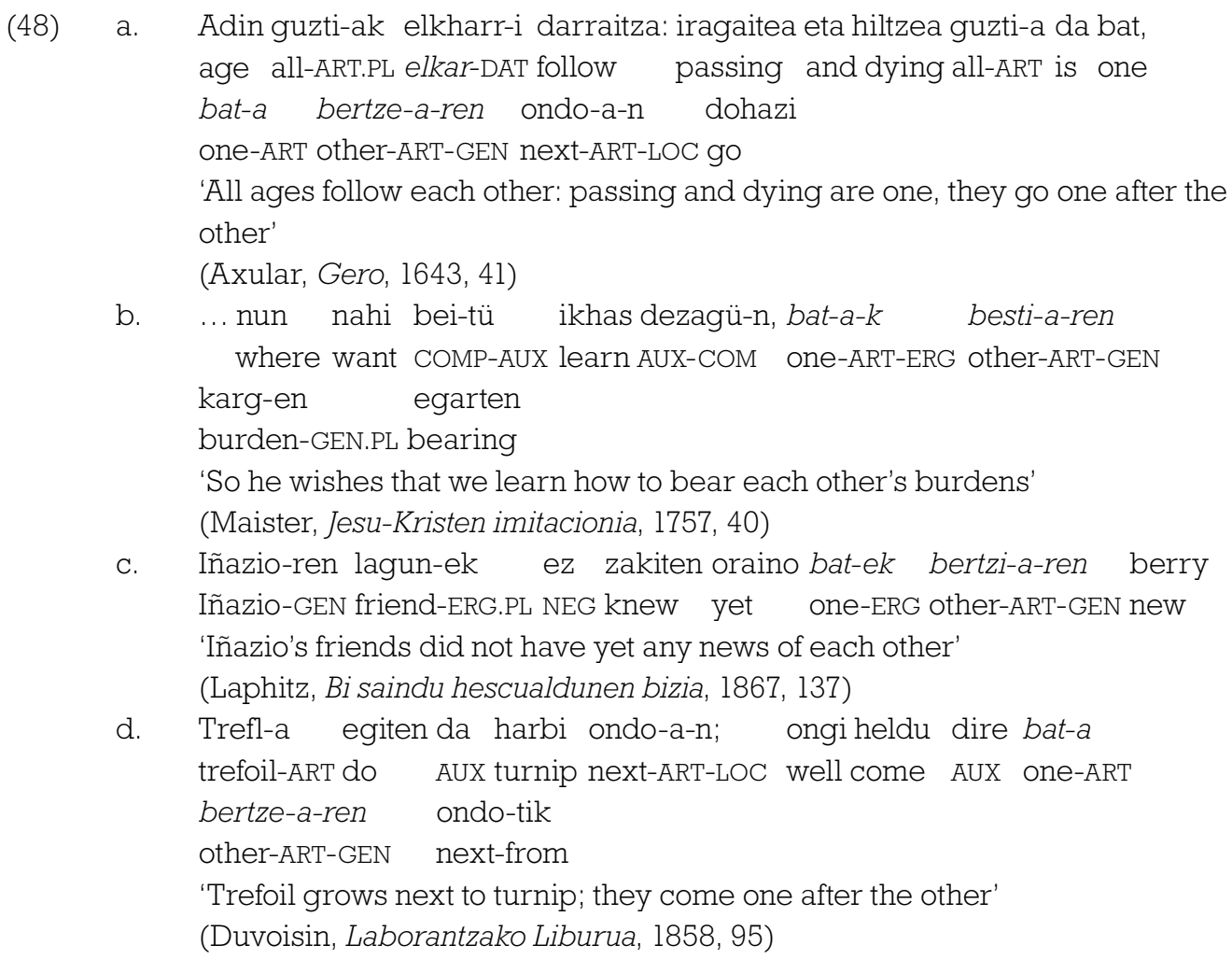

The most typical location nouns and adpositions with which bata bestea shows up are ondo 'next' and kontra 'against', even though pare 'on a par with', leku 'place', gain 'top', alde 'for', and atze 'back' also fairly frequent.

\subsection{When an ergative subject binds the anaphor: distribution of batak bestea vs bata bestea}

Some explanation is in order regarding the use of bata bestea and batak bestea. According to Urrutia, Goitia and Artiagoitia (2013), the use of bata bestea without ergative marking in contexts where the ergative marking seemed perfect is not attested until fairly recently.

First of all, the classical usage is easy to describe: we find the variant batak bestea with ergative case marking on the numeral when the antecedent itself is case marked 
with ergative and the variant bata bestea shows up when the antecedent is an absolutive subject. Again, Leizarraga is a good reference ${ }^{12}$ :
(49) a. Orduan diszipulu-ek bat-a-k berze-a-ganat behatzen zuten then disciple-ERG.PL one-ART-ERG other-ART-to look AUX 'Then the disciples looked at each other' (Leizarraga, 1571, Jn 13, 22)
b. Gogo bat-ez bat-a berze-a-gana afekzionatu-ak zarete-larik will one-INST one-ART other-ART-to affectionate-ART AUX-COMP 'Live in harmony with one another' (Leizarraga, 1571, Rom 12, 16)

The plural DP diszipuluek 'the disciples' binds the anaphor batak berzea and, since the antecedent bears ergative case, so does the (first member of the) anaphor; in the second example, on the other hand, since the subject zuek bears absolutive case, we find a plain bata berzea without ergative on bata.

Table 3. Three patterns for the distinction batak bestea / bata bestea

\begin{tabular}{|c|c|c|c|c|c|c|c|}
\hline \multirow[t]{2}{*}{ Century } & \multirow[t]{2}{*}{ Writer } & \multicolumn{2}{|c|}{ Classical Use } & \multicolumn{2}{|c|}{ Mixed Use } & \multicolumn{2}{|c|}{$\begin{array}{l}\text { Ergativeless } \\
\text { bata bestea }\end{array}$} \\
\hline & & & Dialect & & Dialect & & Dialect \\
\hline \multirow{7}{*}{$17^{\text {th }}$} & Argaiñaratz & $\mathrm{x}$ & $\mathrm{NL}$ & & & & \\
\hline & Axular & $\mathrm{x}$ & $\mathrm{NL}$ & & & & \\
\hline & Belapeire & $\mathrm{x}$ & $S$ & & & & \\
\hline & Etxeberri Dorre & & & & & $\mathrm{x}$ & $\mathrm{NL}$ \\
\hline & Etxeberri of Ziburu & $\mathrm{x}$ & $\mathrm{NL}$ & & & & \\
\hline & Haranburu & $\mathrm{x}$ & $\mathrm{NL}$ & & & & \\
\hline & Pouvreau & $\mathrm{x}$ & $\mathrm{NL}$ & & & & \\
\hline \multirow{7}{*}{$18^{\text {th }}$} & Egiategi & & & $x$ & $S$ & & \\
\hline & Etxeberri of Sara & $\mathrm{x}$ & $\mathrm{NL}$ & & & & \\
\hline & Haraneder & $\mathrm{x}$ & $\mathrm{NL}$ & & & & \\
\hline & Kardaberaz & $\mathrm{x}$ & $\mathrm{C}$ & & & & \\
\hline & Larramendi & $\mathrm{x}$ & $\mathrm{C}$ & & & & \\
\hline & Maister & $\mathrm{x}$ & $S$ & & & & \\
\hline & Mendiburu & $\mathrm{x}$ & $\mathrm{N}$ & & & & \\
\hline
\end{tabular}

12 There is however one example that does not match the pattern:

(i) Ezen guziek bata berzearen ondoan profetiza ahal dezakezue, guziek ikas dezatenzat, eta guziak konsola ditezenzat (Leizarraga, 1 Co 14, 31)

'For all of you can prophesy one after another so that everyone may learn and get console'

The antecedent is the plural ergative guziek; hence one would expect batak berzearen. 


\begin{tabular}{|c|c|c|c|c|c|c|c|}
\hline \multirow[t]{2}{*}{ Century } & \multirow[t]{2}{*}{ Writer } & \multicolumn{2}{|c|}{ Classical Use } & \multicolumn{2}{|c|}{ Mixed Use } & \multicolumn{2}{|c|}{$\begin{array}{l}\text { Ergativeless } \\
\text { bata bestea }\end{array}$} \\
\hline & & & Dialect & & Dialect & & Dialect \\
\hline \multirow{11}{*}{$19^{\text {th }}$} & Astarloa & & & $\mathrm{x}$ & W & & \\
\hline & Azkue. E. & & & & & $\mathrm{x}$ & $\mathrm{W}$ \\
\hline & Duhalde & $\mathrm{x}$ & NL & & & & \\
\hline & Duvoisin & $\mathrm{x}$ & $\mathrm{NL}$ & & & & \\
\hline & Frai Bartolome & & & $\mathrm{x}$ & $\mathrm{W}$ & & \\
\hline & Iturriaga & & & $\mathrm{x}$ & $\mathrm{C}$ & & \\
\hline & Iturzaeta & & & & & $\mathrm{x}$ & $\mathrm{W}$ \\
\hline & Iztueta & $\mathrm{x}$ & $\mathrm{C}$ & & & & \\
\hline & Laphitz & $\mathrm{x}$ & NL & & & & \\
\hline & Lardizabal & $\mathrm{x}$ & $\mathrm{C}$ & & & & \\
\hline & Mogel, J. A. & & & $\mathrm{x}$ & $\mathrm{W}$ & & \\
\hline \multirow{14}{*}{$20^{\text {th }}$} & Agirre, Tx. & $\mathrm{x}$ & $\mathrm{W}, \mathrm{C}$ & & & & \\
\hline & Barbier & $\mathrm{x}$ & NL & & & & \\
\hline & Enbeita, K. & & & & & $\mathrm{x}$ & $\mathrm{W}$ \\
\hline & Etxepare Landerretxe & $\mathrm{x}$ & NL & & & & \\
\hline & Etxepare, J. & $\mathrm{x}$ & $\mathrm{NL}$ & & & & \\
\hline & Goikoetxea, J. I. Gaztelu & & & & & $\mathrm{x}$ & $\mathrm{C}$ \\
\hline & Hiriart-Urruty & $\mathrm{x}$ & $\mathrm{NL}$ & & & & \\
\hline & Kirikiño & & & $\mathrm{x}$ & $\mathrm{W}$ & & \\
\hline & Mirande & & & $\mathrm{x}$ & SB & & \\
\hline & Mitxelena & $\mathrm{x}$ & SB & & & & \\
\hline & Orixe & & & $\mathrm{x}$ & $\mathrm{C}$ & & \\
\hline & Txirrita & & & & & $\mathrm{x}$ & $\mathrm{C}$ \\
\hline & Villasante & & & & & $\mathrm{x}$ & $\mathrm{C}$ \\
\hline & Xalbador & & & $\mathrm{x}$ & $\mathrm{NL}$ & & \\
\hline
\end{tabular}

A close scrutiny of the Basque literary tradition reveals three patters of use: the authors, a vast majority, who basically follow Leizarraga's tendency; those who alternate the ergative-less variant and the one with ergative in contexts which would require a consistent use; and, thirdly, the authors that systematically avoid the use of the pseudo-anaphor, to put it in De Rijk's terms. Table 3 is a comprehensive summary of each writer's pattern. 
As representatives of the second, mixed-up, pattern we can cite Egiategi and Mirande. Even though for most part he sticks to Leizarraga's classical usage, Egiategi (1785) has a good example where the barrier between the two variants appears blurred:

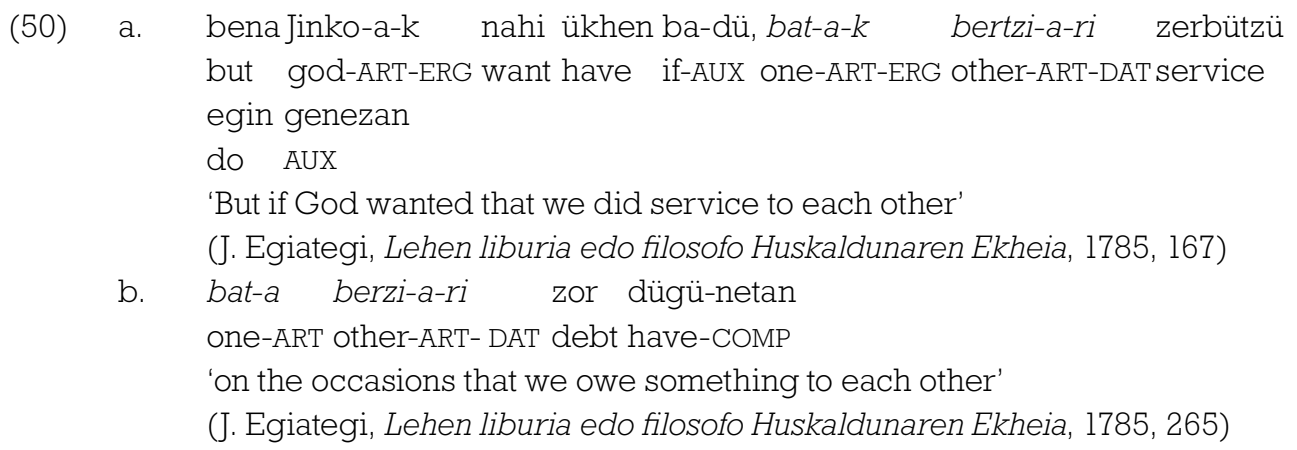

Unless something is missing, an ergative case marked pro corresponding to the first person plural guk would be the antecedent of bata ber(t)zia in both cases, yet we only see the ergative case marking on bata in the first one. In Mirande's Haur Besoetakoa we also find both the ergatively case-marked and the ergative-less case marked versions of bata bestea in contexts where the antecedent bears ergative case:

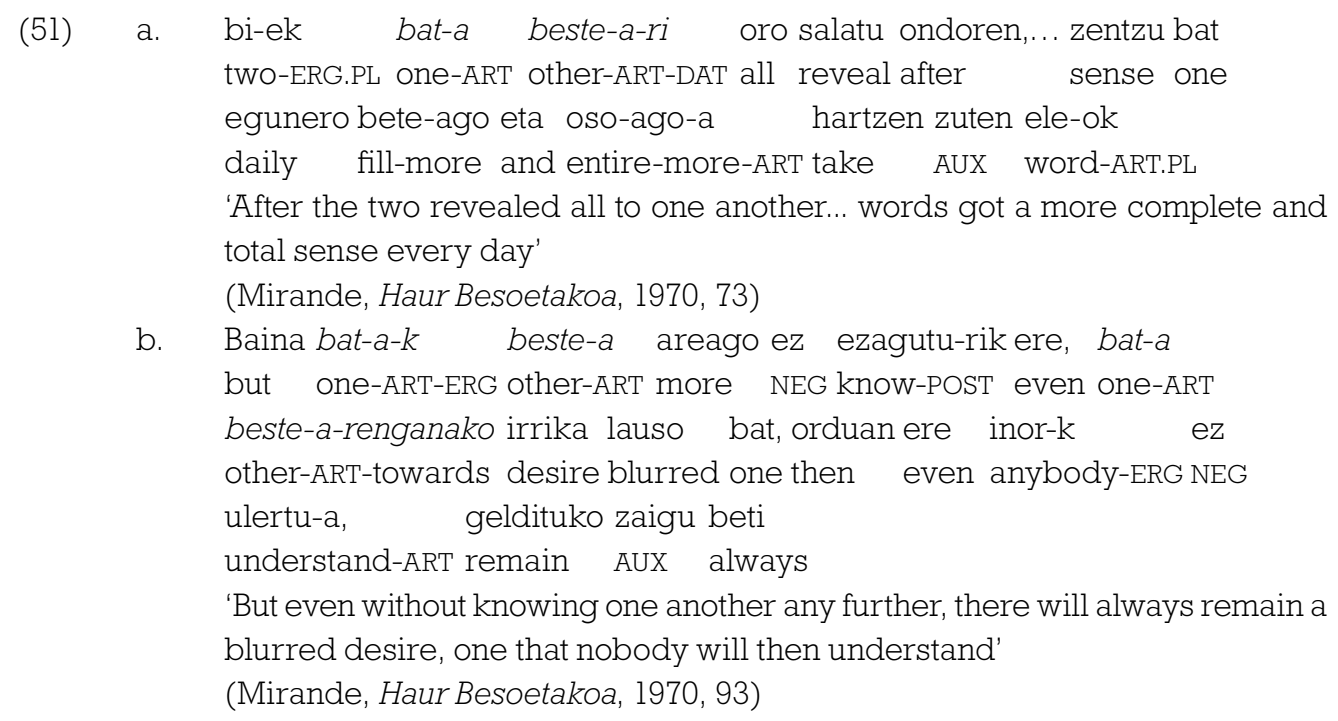

My interpretation of the facts is that in [batak bestea areago ezaguturik ere] the subject is a silent pronominal (i.e. PRO) equivalent to guk 'we-ERG' and that the anaphor batak bestea is in object positon; thus, it turns out that Mirande pattern is contradictory. Other authors which display a similar behaviour are Astarloa, Frai Bartolome, J. A. Mogel, Iturriaga, Kirikiño, Orixe and Xalbador, the first three from the 19th century and the latter four from the 20th century. 
Let us turn now to the authors that systematically use the true anaphor bata bestea without case marking on the first member bata even the antecedent is an ergative subject: Iturzaeta and Juan Ignacio Goikoetxea Gaztelu are representatives of these pattern:

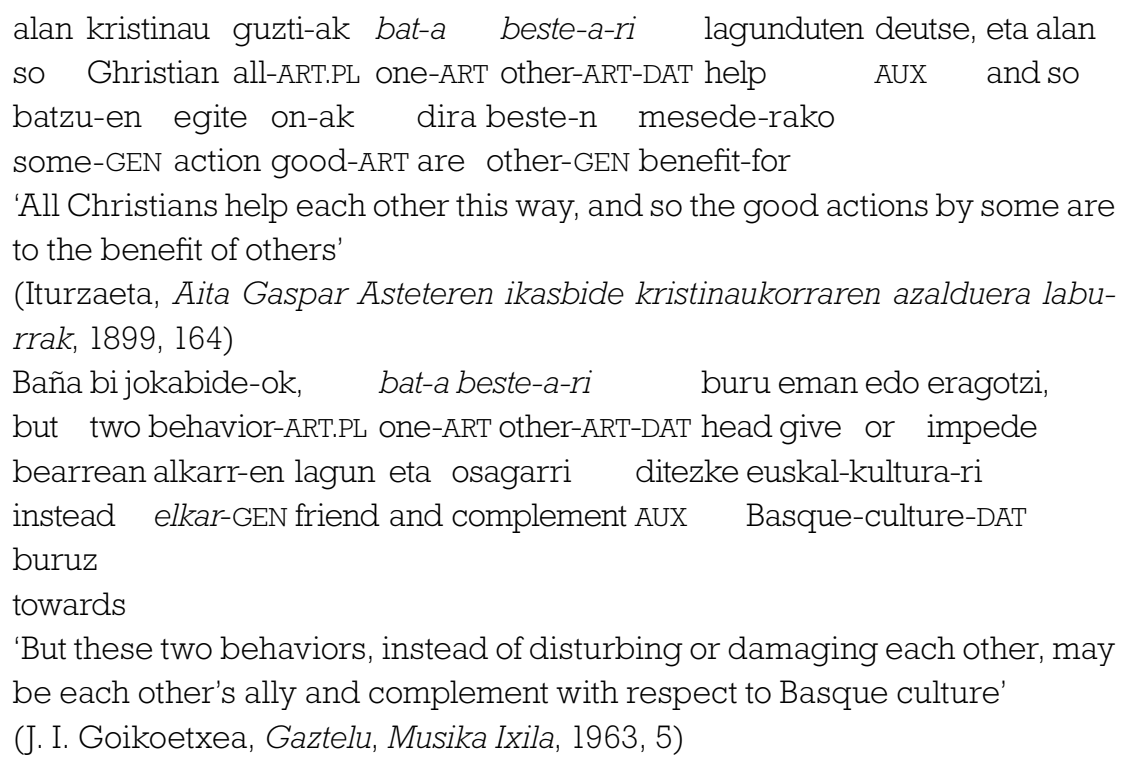

It should be pointed out that these authors are quite modern, either from the end of the 19th century or from the 20th century; one could add Eusebio Azkue, Txirrita, Kepa Enbeita and Villasante (in the book Kristau fedearen sustraiak. I. Jainkoa at least) to the list, again the three belonging to the same period (late 19th century-20th century) ${ }^{13}$. It is also worth bearing in mind that the Navarro-Labourdin data reported by Rebuschi in all his articles on the subject always refer to the ergative-less variant bata bestea as the dominant in spoken Basque; HEE describe the same situation for Lekeitio Basque ${ }^{14}$.

Nonetheless, despite the impression one might get, many of the 19th and 20th century writers such as Duvoisin, Iztueta, Laphitz, Lardizabal, Txomin Agirre, Barbier, Jean Etxepare, Hiriart-Urruty, Etxeita, Jean Etxepare Landerretxe or Mitxelena keep on using the classical pattern and case-marking the first member bata of the anaphor with ergative if the antecedent is an ergative DP; the same is true of previous authors such as Argaiñaratz, Axular, Belapeire, Etxeberri of Ziburu, Haranburu, Pouvreau, Duhalde, Egiategi, Etxeberri of Sara, Haraneder, Larramendi, Kardaberaz, Maister, Mendiburu. A comprehensive study of the usage in both the 20th and 21st centuries would shed more light on this variation. For the time being, one can simply say that, with the apparently random exception of Etxeberri Dorre (1677), it is not until the

13 Piarres Etxeberri Dorre's Itxasoko Nabigazionekoa (1677) is an isolated, single, case of an ergative-less variant in the only potential example attested. Hence, he too could be added to the list.

14 And the same seems to be true for Mallabia (K. Zuazo, p. c.) and Forua \& Gernika (I. Arteatx, p. c.). 
1800 s that we start seeing a weakening of the ergative marking on batak bestea when the antecedent is an ergative subject ${ }^{15}$.

\subsection{On Rebuschi's (1993) unfulfilled predictions}

A look into the Basque literary tradition allows one to additionally check the predictions made by Rebuschi (1993), with some surprising results. As I said in section 4.2, in his analysis of today's Navarro-Labourdin Basque, Rebuschi's (1993) renewed account predicts that the anaphor bata bestea will be excluded from two syntactic contexts: from the object position of verbs and the object position of a relational noun ${ }^{16}$. The examples already given above in $(41,42,49$ a) show that the prediction is not fulfilled for Leizarraga's texts.

However, these examples need not match the present situation in Navarro-Labourdin Basque; as a matter of fact, Rebuschi himself (1993, p. 122) remarks in a footnote that examples of bata bestea in the verb's object position can be found and that his account is limited to the present day situation. The point is that this type of example is in fact wide spread along the Basque literary tradition, both in Navarro-Labourdin Basque and outside that dialect. Below I provide two additional examples:

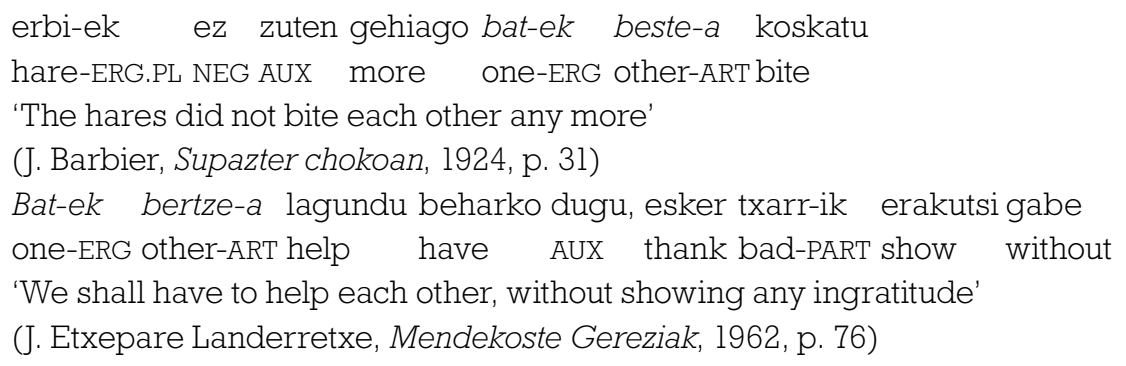

15 A superficial look at the Comtemporary Reference Prose corpus reveals that the tendency for distinguishing batak bestea and bata bestea is still operative in the $21^{\text {st }}$ century, with a majoritiy of writers sticking to the distinction:

(i) a. antropofagia apur batekin besarkatu dugu batak bestea (J. Sarrionandia, Lagun izoztua, 424, 2001)

'We hugged one another with a little anthrophofagy'

b. Batek bertzea laguntzen dute, osatzen dute, eta enetako egiten da hola... (M. Oxandabaratz, Ez da musik, 2006, p. 119)

'They help, complement, one another, and in my opinion it is done so...'

But, ocassionally, some writers turn to the ergative-less variant:

(ii) Bitartean, bata bestea tristatzen dute (J. Renard-I. Otegi, Axenario, 2006, p. 88)

'Meanwhile, they sadden one another'

16 There is, in fact, a third context, namely bata bestea in locational phrases with perception verbs bound by the absolutive argument that agrees with the verb:

(i) $\quad$ Haiek $_{\mathrm{i}}$ sugeak $_{\mathrm{j}}$ bata bertze-a-ren ${ }_{\mathrm{i} / \text { ?? }}$ ondoan ikusi dituzte (Rebuschi, 1993, p. 122)

they snakes one-ART other-ART-GEN near see AUX

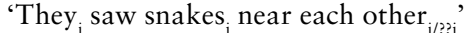

According to Urrutia, Goitia and Artiagoitia (2013) most speakers do not agree with the judgements provided by Rebuschi. 
Rebuschi's first prediction has a secondary tie related to the so called TO-GEN structure (Heath, 1972): if bata bestea cannot be an object to a verb, it will hardly show up as a genitive in nominalizations that permit the alternation between absolutive and genitive cases. But this prediction is not borne out either:

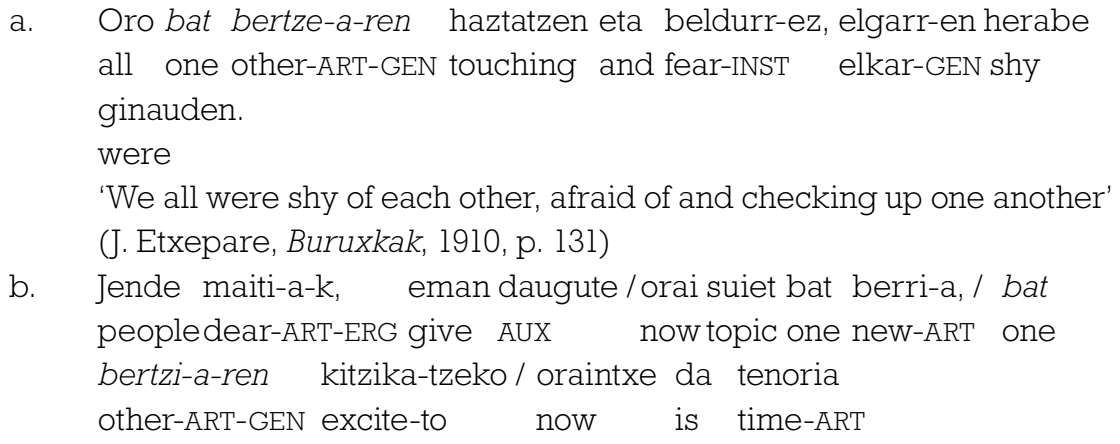

Etxepare's example is significant because the anaphor is both a complement to a nominalized verb and to the relational noun beldur 'fear' (bearing the instrumental adposition). Regarding this latter syntactic context, that of complement of a relational noun, the examples are scarcer, but some can be provided:

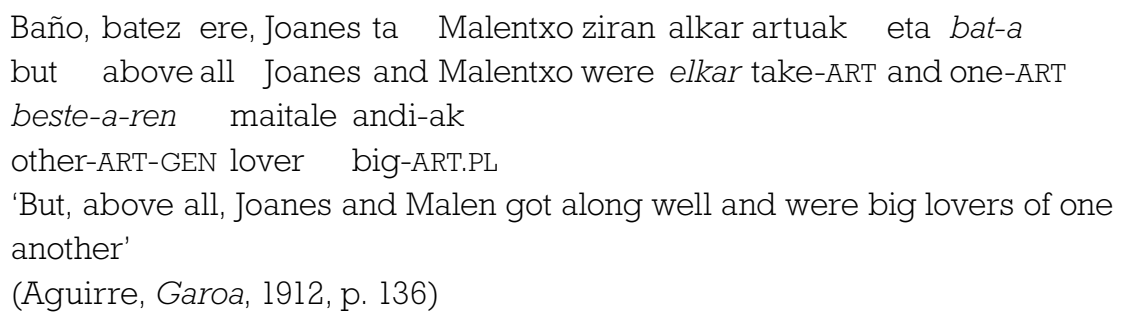

These are examples by authors from the Spanish side of the border, but there also some from Navarro-Labourdin writers, too:

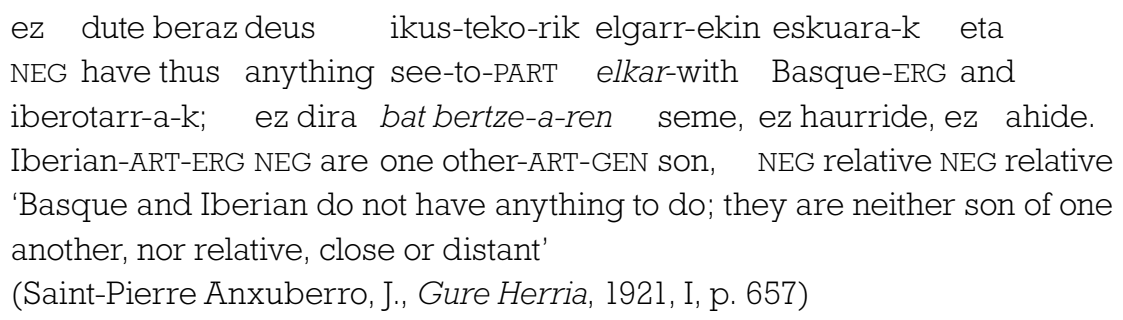

In view of all these examples, we can conclude (a) that the proposal made by Rebuschi (1993) predicts a slightly different distribution for bata bestea, a prediction which is not confirmed by the data; and (b) that this anaphor can in fact appear in complement 
position of both verbs and nouns. This, in turn, simply means that the account developed in Rebuschi $(1988,1989)$ is more appropiate. We summarize it below:

$$
\text { Reciprocal anaphors in (Navarro-Labourdin) Basque }
$$

\begin{tabular}{|l|c|c|}
\hline Anaphor & Narrow Binding Domain & Wide Binding Domain \\
\hline elkar & bound & bound \\
\hline bata bestea & bound or free & bound \\
\hline
\end{tabular}

In principle, the NBD and WBD would be defined as (35-36) above; for those speakers (cfr. footnote 7) who allow elkar in the subject position inside a noun phrase (i. e. as a true possessor genitive), then the condition for elkar should be re-formulated. Finally, although more research is needed, in principle all dialects pattern with Navarro-Labourdin with respect to the use of bata bestea.

\section{NOTES FOR FURTHER STUDY}

In this section I make a few remarks on the differences between bata bestea and elkar that should lay the basis for a future account. These remarks have to do with the possibility of finding bata bestea but not elkar in finite subject position, the possibility of elkar's having a singular binder, the different distribution of the two anaphors with symmetric predicates, and the different interpretation both anaphors give rise to.

\subsection{Subject reciprocal anaphors?}

One interesting property of bata bestea is that it can surface as coda in comparative clauses. Here are some $20^{\text {th }}$ century examples from Northern writers:

(60) a. Heia handi bat-ean etzan-ak ikusi zituen zazpi behor, bat bertze-a bezen stable big one-LOC lie-ART.PL see AUX seven mare one other-ART as ederr-ak

\section{beautiful-ART}

'He saw seven mares lying on a big stable, as beautiful as one another' (J. Barbier, Légendes du Pays Basque, 1931, p. 128)

b. Jainko-a-k bi mirakuilu, bat bertze-a bezen ohartgarri-ak, egin god-ART-ERG two miracle one other-ART as remarkable-ART.PL do zituen Gedeon-en bixta-n

AUX Gedeon-GEN sight-LOC

'God made two miracles, as remarkable as one another, at the sight of Gedeon' (J. Elissalde «Zerbitzari», Ichtorio Saindua. Testament Zaharra. Jesu-Christo. Eliza, 1943, p. 46)

C. Andrea eta biak, / haurr-a-rekin hiru, / batbertzi-a bezen trixte / wife-ART and two-ART.PL child-ART-with three one other-ART as sad 


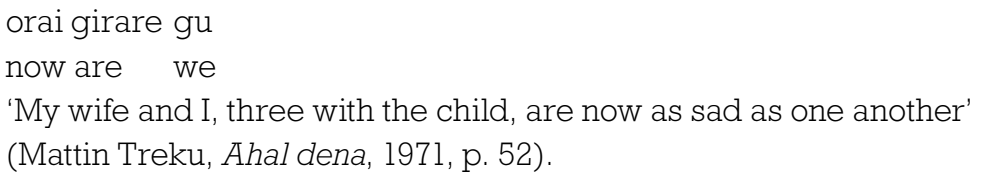

The interesting point is that elkar is ungrammatical in this kind of sentences as substituting bata bertzea for elkar in an example like (60a) clearly shows:

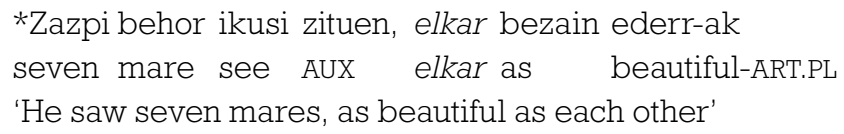

Although little research has been conducted on Basque comparative structures ( $c f r$. Sáez, 1989; Goenaga, 2012), it is generally assumed that the coda part of comparatives hide a full sentencial structure:

$$
\begin{aligned}
& \text { Ikusi zituen zazpi behor, zureak (ederrak diren) bezain ederrak } \\
& \text { 'He saw seven mares, as beautiful as yours (are beautiful) }
\end{aligned}
$$

If so, then one must assume that sentences like the ones above in (60) hide a full clausal structure where the anaphor is in finite subject position:

$$
\begin{aligned}
& \text { Ikusi zituen zazpi behor, bat bertze-a dir-en bezain ederr-ak } \\
& \text { see Aux seven mare one other-ART are-COMP as beautiful-ART.PL } \\
& \text { 'He saw seven mares, as beautiful as one another are' (cfr. 60a \& 62) }
\end{aligned}
$$

The idea that bata bestea can be a finite clause subject is potentially confirmed by these two examples, although the judgements need further confirmation:

$$
\begin{aligned}
& \text { Alaere, Fray Luisen odaren eskupe osoa ez datza aapalditzat «lira» dulakoan, } \\
& \text { atalkin auetzaz olertitza nola osatzen dunean, bata besteak guziarekin duten } \\
& \text { ar-emanetan baizik } \\
& \text { 'The power of Fray Luis's ode does not lie in that the he uses the lira as stro- } \\
& \text { phe, or in how he composes poetry with these ingredients, but in the rela- } \\
& \text { tionship that one another have with everything' } \\
& \text { (J. I. Goikoetxea Gaztelu, Musika ixilla, 1963, p. 64). } \\
& \text { ês-takiže bat-a-bestí-a-k ser égingo dabe-n (=4b) } \\
& \text { NEG-know one-ART-other-ART-ERG what do AUX-COMP } \\
& \text { 'They do not know what each other will do' }
\end{aligned}
$$

Depending on the interpretation, Goikoetxea's example is amenable, perhaps, to an analysis where the discourse antecedent of the anaphor bata bestea is split between two separate (singular) noun phrases (poetry and lira); note, besides, that the anaphor has plural agreement with the finite verb, contrary to what we see in the Lekeitio Basque example. 
In any case, binding of the subject anaphor bata bestea by a subject that it is not the one immediately c-commanding it is discarded, as we saw in example (25b).

\subsection{Singular and plural antecedents}

A second difference between bata bestea and elkar has to do with the latter's possibility of having a singular (though collective and/or semantically plural) antecedent:
a. Herri-eta-n jende-a-k elkar ezagutzen du
village-PL-LOC people-ART-ERG elkar know AUX
'In the villages, people know each other'
$(\text { Argia, 2001) })^{17}$
b. Matrimoniyo ondo artu-ba-k/ alkarr-i asko zor diyo
marriage well take-ART-ERG elkar-DAT much debt AUX
'A married couple that gets along well ows each other a lot'
(P. Elizegi, Errota, Pello Errotakjarritako bertsoak, 1963, p. 136)

In the same contexts, the speakers consulted reject the use of bata bestea:
a. *Herrietan jendeak batak bestea ezagutzen du
b. *Matrimonio ondo hartuak batak besteari asko zor dio

Given the makeup of bata bestea (a bipartite anaphor with two noun phrases with explicit number marking), this is hardly a surprise. The possibility of finding elkar in impersonal sentences with arbitrary PRO may be related to its ability to have a singular binder; no such possibility exists for bata bestea:
(68) a. Ai, maita-tzeko, alkar ezautu / bear da len-ago. love-to elkar know have AUX first-more
'To love, it is first necessary to know each other'
(L. Jauregi Jautarkol, Biozkadak, 1929, p. 72)
b. *Maitatzeko, batak bestea ezagutu behar da lehenago
'To love, it is first necessary to know each other'

\subsection{Symmetric and alignment predicates}

As explained in Bosque (1985), reciprocity often is related to bidirectional predicates, which sometimes have nothing to do with syntactical strategies of reciprocalization. For example, John and Mary love each other, with a true reciprocal pronoun, is equivalent to a bidirectional relationship such that «John loves Mary and Mary loves John»; but a similar bidirectional relationship can be established in the case of

17 Retrieved from: http://www.argia.eus/argia-astekaria/1811/sindikalistak-irabazitako-borroketatik-ikasi-behar-du 
John and Mary are teammates (John is Mary's teammate and Mary is John's teammate) without a reciprocalization strategy being involved. In other words, semantic bidirectionality need not be related to syntactic reciprocality. And, of course, the situation can also be reversed: there might be syntactically reciprocal constructions that are not strictly related to semantic reciprocality. This may well help us understand another interpretive difference between elkar and bata bestea. In the case of predicates that denote a linear arrangement or alignment in terms of time or location, bata bestea is used but elkar is out. For example in the case of matryoshka boxes, dolls are arranged so that they are one inside the other, but this is hardly ever a symmetric relation (if A doll is inside the B doll, then the B doll cannot be inside the A doll). In cases like this, elkar is ungrammatical but bata bestea is precisely the anaphor required:

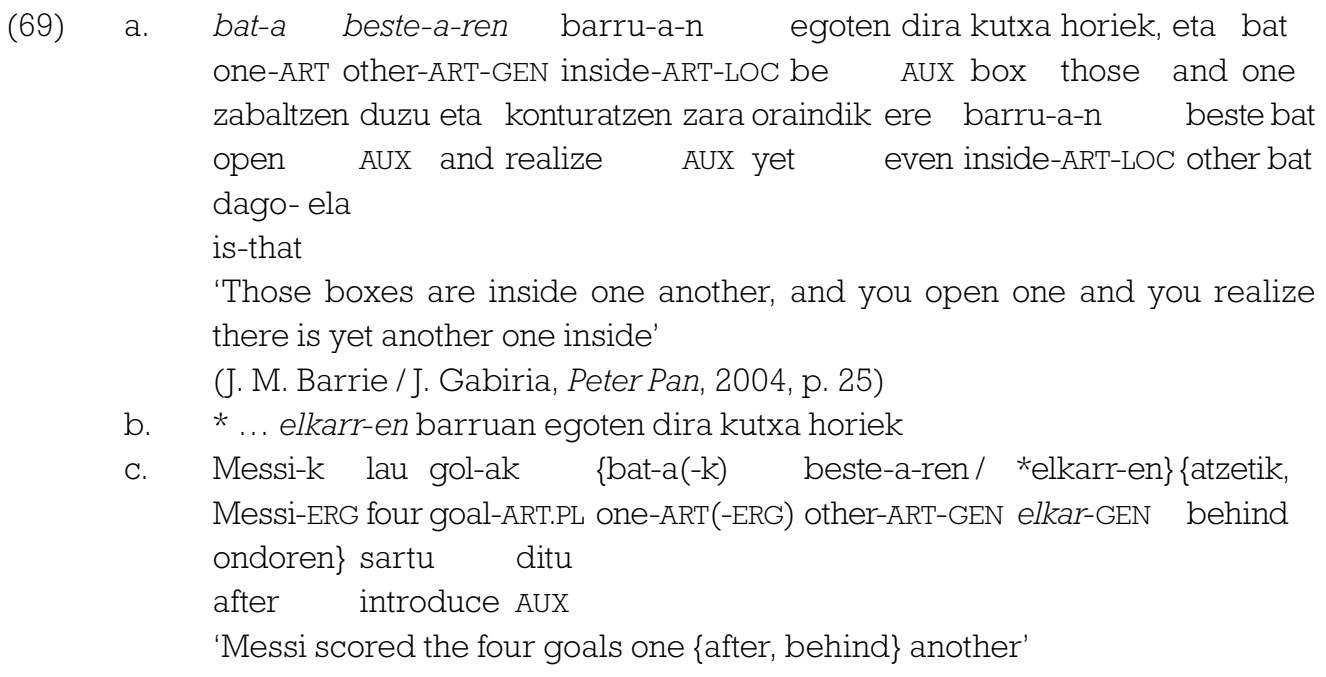

In other words, given that the locational or temporal arrangement of dolls and goals cannot accept a symmetric (or bidirectional) reading, only bata bestea can be used here.

\subsection{Group reading}

Although the differences and the judgements are rather subtle, it seems that both anaphors give rise to interpretations that need not coincide. This is particularly true in the following example with the anaphors as complement to the comitative adposition -ekin:
a. Bost irakasleok elkarrekin eztabaidatu dugu proposamena
'The five teachers discussed the proposal \{together / with each other\}'
b. Bost irakasleok batak bestearekin eztabaidatu dugu proposamena
'The five teachers discussed the proposal with one another'

The first sentence is compatible with a situation where the group of five teachers have discussed the proposal in a single, group, discussion; this is in fact the most salient reading, although it is not the only one available (it might well be the case that several 
discussions have taken place so that the five teachers have taken part after all); for the (b) sentence, the group reading is impossible and more than one discussion has necessarily taken place.

A similar situation obtains when the anaphors are in argument position:
a. Bost irakasleok elkar besarkatu dugu
'The five teachers hugged each other'
b. Bost irakasleok batak bestea besarkatu dugu
'The five teachers hugged each other'

Sentence (71a) is compatible with a groupal hug and there is no need (although it is certainly a possibility) to have a sequence of mutual hugs between two people; the second sentence, on the other hand, only has this second reading (with more mutual hugs). In this regard, then, the reciprocity invoked by elkar is weaker than that displayed by bata bestea.

It is of course tempting to relate these interpretive differences between the two anaphors to their different morphological makeup: a bipartite noun phrase with an quantifier member in the case of bata bestea (and the first member even bearing the same case marking as the subject) and a morphological simple form in the case of elkar (synchronically at least). For anaphors like the latter, a raising analysis has been proposed in the literature (Belletti, 1982; Heim, Lasnik \& May, 1991) which capitalize on the quantifier nature of the anaphor and, thus, propose that the quantifier each/one (bata in Basque) raises to the matrix subject at LF. Although the raising analysis as conceived by Heim, Lasnik and May is probably on the wrong track ( $c f r$. Dalrymple, Mchombo $\&$ Peters, 1994), some aspects of it seem worth pursuing.

\section{CONCLUSIONS}

This article has revised the morphosyntactic makeup of the two most usual reciprocal anaphors in Basque, viz. bata bestea and elkar; the first one is a bipartite quantificational anaphor (similar to English one another or each other) and the other is a single reciprocal nominal (originally also a bipartite consisting of the two distal demonstratives); Evans's (2008, p. 47) suggestion that bipartite quantificational anaphors of the each other / one another type proliferated in Europe due to biblical translations is certainly compatible with the Basque data on bata bestea, the first systematic use of which corresponds to Leizarraga's (1571) work, a translation of the New Testament.

I have shown that the bipartite anaphor bata bestea is attested from the $16^{\text {th }}$ century texts on across all dialects and periods, and that the alleged restriction of bata bestea not to appear in complement position to nouns or verbs defended by Rebuschi (1993) is not confirmed by the data. Instead, it seems that Rebuschi's $(1988,1989)$ first account of the distribution of elkar and bata bestea is on the right track: for the majority 
of speakers, the former is a narrower reciprocal anaphor in the sense that it has to be bound in the domain of the first available subject. The latter, on the other hand, is a wider reciprocal anaphor given that it only has to be bound in the domain of a c-commanding subject; hence, it can itself be a subject.

The research has also revealed that article-less variant of bata bestea (i. e. bat bestea/bertzea) is a fairly recent phenomenon (from the $19^{\text {th }}$ century on) circumscribed to authors to Navarro-Labourdin or Souletin dialects. The distinction between $b a-$ tak bestea and bata bestea starts blurring in the case of some authors towards the end of the $18^{\text {th }}$ century and the beginning of the $19^{\text {th }}$, but most writers keep the distinction whenever the binder is an ergative subject. Finally, I have sketched a few further differences between the two anaphors in section 6; analyzing these differences should pave the way to a proper and thorough analysis of the two anaphors in the future.

\section{REFERENCES}

Artiagoitia, X. (2000). Hatsarreak eta parametroak lantzen. Gasteiz: UPV/EHU-Arabako Foru Aldundia.

Artiagoitia, X. (2003). Reciprocal and reflexive constructions. In J. I. Hualde \& J. Ortiz de Urbina (eds.), A Grammar of Basque (p. 607-632). Berlin: Mouton de Gruyter.

Azkue, R. M. de. (1923). Morfología vasca. Bilbao: La Gran Enciclopedia Vasca.

Belleti, A. (1982). On the Anaphoric Status of the Reciprocal Construction in Italian. Linguistic Review, 2, 101-137.

Bosque, I. (1985). Sobre las oraciones recíprocas en español. Revista Española de Lingüística, 15(1), 59-96.

Chomsky, N. (1981). Lectures on Government and Binding. Dordrecht: Foris.

Chomsky, N. (1986). Knowledge of Language. New York: Praeger.

Dalrymple, M., Mchombo, S. A. \& Peters, S. (1994). Semantic similarities and syntactic constrasts between Chichewa and English reciprocals. Linguistic Inquiry, 25, 145-163.

De Rijk, R. P. G. (2008). Standard Basque. A progressive grammar. Cambridge MA: MIT Press.

Euskaltzaindia. (1985). Euskal gramatika. Lehen urratsak-I. Bilbao: Euskaltzaindia.

Euskaltzaindia. (1987). Euskal gramatika. Lehen urratsak-II. Bilbao: Euskaltzaindia.

Euskaltzaindia. (1993). Euskal gramatika laburra: Perpaus Bakuna. Bilbao: Euskaltzaindia.

Euskaltzaindia. (2016). Euskaltzaindiaren Hiztegia. Bilbao: Euskaltzaindia.

Etxepare, R. (2003). Valency and argument structure in the Basque verb. In J. I. Hualde \& J. Ortiz de Urbina (eds.), A Grammar of Basque (p. 363-425). Berlin: Mouton de Gruyter.

Evans, N. (2008). Reciprocal constructions: Towards a structural typology. In E. König $\&$ V. Gast (eds.), Reciprocals and reflexives. Theoretical and typological explorations (p. 33-104). Berlin: Mouton de Gruyter. 
Everaert, M. (2000). Types of anaphoric expressions. In Z. Frajzyngier \& T. Walker (eds.), Reciprocals: Forms and Functions (p. 63-83). Amsterdam: John Benjamins.

Everaert, M. (2005). Long-distance reciprocals. H. Broekhuis, C. Corver, J. Koster, M. A. C. Huybregts \& U. Kleinhenz (eds.), Organizing Grammar: Linguistic studies for Henk van Riemsdijk (p. 127-137). Berlin: Mouton de Gruyter.

Everaert, M. (2008). Domain restrictions on reciprocal interpretation. In E. König \& V. Gast (eds.), Reciprocals and Reflexives. Theoretical and Cross-linguistic Explorations (p. 557-576). Berlin: Mouton de Gruyter.

Faltz, L. (1985). Reflexivization. A Study in Universal Syntax. New York: Garland.

Gèze, L. (1873). Éléments de grammaire basque, dialecte souletin, suivi d'un vocabulaire basque-français \& français-basque. Baiona: Lamaignère.

Goenaga, P. (1980). Gramatika bideetan. Donostia: Erein.

Goenaga, P. (2012). An overview of Basque measure phrases. In U. Etxeberria, R. Etxepare \& M. Uribe-Etxebarria (eds.), Noun phrases and Nominalization in Basque (p. 111-148). Amsterdam: John Benjamins.

Haspelmath, M. (2007). Further remarks on reciprocal constructions. In V. P. Nedjalkow (ed.), Typology of reciprocal constructions, volume 4 (p. 20872115). Amsterdam: John Benjamins.

Heath, J. (1972). Genitivization in Complement Clauses. Anuario del Seminario de Filología Vasca "Julio de Urquijo», 6, 46-66.

Heim, I., Lasnik, H. \& May, R. (1991). Reciprocity and plurality. Linguistic Inquiry, 22, 63-101.

Hornstein, N. (2001). Move! A minimalist theory of construal. Malden: Blackwell.

Hualde, J. I., Elordieta, G. \& Elordieta, A. (1994). The Basque dialect of Lekeitio. Donostia. (Supplements of ASJU, 34).

Ithurry, J. (1895). Grammaire basque. Dialect labourdin. Bayonne \& Biarritz: Lamaignère.

König, E. \& Kokutani, S. (2006). Towards a typology of reciprocal constructions: focus on German and Japanese. Linguistics, 44(2), 271-302.

Koster, J. (1985). Reflexives in Dutch. In J. Guéron, H.-G. Obenauer \& J.-Y. Pollock (eds.), Grammatical Representation (p. 141-167). Dordrecht: Foris.

Koster, J. (1987). Domains and Dynasties. Dordrecht: Foris.

Lafitte, P. (1962). Grammaire basque (navarro-labourdin littéraire). Bayonne: Ikas.

Mitxelena, L. (1977). Fonética histórica vasca. San Sebastián: Diputación Foral de Guipúzcoa.

Mitxelena, L. \& Sarasola, I. (1987-2011). Diccionario general vasco-Orotariko euskal hiztegia (OEH). 2nd edition. Bilbao: Euskaltzaindia/Desclée de Brouwer. Retrieved from http://www.euskaltzaindia.eus/index.php?option=com_co ntent\&view=article\&id=276\&Itemid=413\&lang=eu

Ormazabal, J. \& Romero, J. (2010). The derivation of dative alternations. In M. Duguine, S. Huidobro \& N. Madariaga (eds), Argument Structure and Syntactic Relations (p. 203-232). Amsterdam: John Benjamins.

Ortiz de Urbina, J. (1989). Parameters in the Grammar of Basque. Dordrecht: Foris. 
Oyharçabal, B. (2010). Basque ditransitives. In M. Duguine, S. Huidobro \& N. Madariaga (eds.), Argument Structure and Syntactic Relations (p. 233-260). Amsterdam: John Benjamins.

Picallo, C. (2015). Ligamiento y control. In A. Gallego (ed.), Perspectivas de sintaxis formal (p. 463-511). Madrid: Akal.

Rebuschi, G. (1988). Defining the three Binding Domains of Basque. Anuario del Seminario de Filología Vasca "Julio de Urquijo", 22(1), 233-241.

Rebuschi, G. (1989). La problematique de la localité dans la théorie du liage. In P. Salaburu (ed.), Sintaxi Teoria eta Euskara (p. 121-141). Bilbao: UPV/EHU.

Rebuschi, G. (1992). Absolute and Relativized Locality in the Binding Theory. In J. Lakarra \& J. Ortiz de Urbina (eds.), Syntactic Theory and Basque Syntax (p. 343-363). Donostia. (Supplements of ASJU, 27).

Rebuschi, G. (1993). Basque Pronouns and Relativized Locality. J. I. Hualde \& J. Ortiz de Urbina (eds.), Generative Studies in Basque Linguistics (p. 115-144). Amsterdam: John Benjamins.

Reuland, E. (2011). Anaphora and Language Design. Cambridge MA: MIT Press.

Sáez, L. (1989). Borrado/Forma Lógica: comparativas con complemento nulo en español y en euskera. Anuario del Seminario de Filología Vasca «Julio de Urquijo», 23(3), 677-700.

Salaburu, P. (1985). Uztardura. In J. L. Melena (ed.), Symbolae Ludovico Mitxelena Septuagenario Oblatae (p. 987-994). Vitoria-Gasteiz: UPV/EHU.

Salaburu, P. (1986a). La teoría del ligamento en la lengua vasca. Anuario del Seminario de Filología Vasca «Julio de Urquijo», 20(2), 359-413.

Salaburu, P. (1986b). Uztardura teoria. In P. Goenaga (ed.), Euskal sintaxiaren zenbait arazo (p. 59-94). Bilbao: UPV/EHU.

Saltarelli, M. (1988). Basque. London: Croom Helm.

Sarasola, I. (2008-2018). Egungo euskararen hiztegia. Leioa: UPV/EHU. Hemendik hartua: https://www.ehu.eus/eeh/

Siloni, T. (2012). Reciprocal verbs and symmetry. Natural Language and Linguistic Theory, 30, 261-320.

Villasante, L. (1980). Sintaxis de la oración simple. Oñati: EFA.

Trask, R. L. (1997). The History of Basque. London: Routledge.

Txillardegi (1978). Euskal gramatika. Donostia: Ediciones Vascas.

Urrutia, A., Goitia, B. \& Artiagoitia, X. (2013). Bata bestea anafora elkarkariaren inguruan. Manuscript. UPV/EHU.

Zuazo, K. (2014). Euskalkiak. Donostia: Elkar.

\section{Sources of examples}

Classic Basque Corpus: https://www.ehu.eus/en/web/eins/euskal-klasikoen-corpusa Klasikoen Gordailua [Repository of the Classics]: http://klasikoak.armiarma.com/

Orotariko Euskal Hiztegia [Basque General Dictionary]: http://www.euskaltzaindia. net/oeh.

XX. mendeko euskararen corpus estatistikoa/ $20^{\text {th }}$ Century Basque statistical corpus: http://xxmendea.euskaltzaindia.eus/Corpus/ 